\title{
Responses of Larix principis-rupprechtii Radial Growth to Climatic Factors at Different Elevations on Guancen Mountain, North-Central China
}

\author{
Jiachuan Wang ${ }^{1,2} \mathbb{D}^{-}$, Shuheng $\mathrm{Li}^{1,2, *}$, Yili Guo ${ }^{1,2}$, Qi Yang ${ }^{1,2}$, Rui Ren ${ }^{1,2}$ and Yijie Han ${ }^{1,2}$ \\ 1 College of Urban and Environmental Science, Northwest University, Xi'an 710127, China; \\ jiachuanwang2020@163.com (J.W.); GuoYili2021@163.com (Y.G.); yangqi547@163.com (Q.Y.); \\ renrui5213@163.com (R.R.); yjhan229@163.com (Y.H.) \\ 2 Shaanxi Key Laboratory of Earth Surface System and Environmental Carrying Capacity, \\ Northwest University, Xi' an 710127, China \\ * Correspondence: lish@nwu.edu.cn; Tel.: +86-29-8830-8418
}

Citation: Wang, J.; Li, S.; Guo, Y.; Yang, Q.; Ren, R.; Han, Y. Responses of Larix principis-rupprechtii Radial Growth to Climatic Factors at Different Elevations on Guancen Mountain, North-Central China. Forests 2022, 13, 99. https:// doi.org/10.3390/f13010099

Academic Editor: Marcello Vitale

Received: 19 December 2021

Accepted: 7 January 2022

Published: 11 January 2022

Publisher's Note: MDPI stays neutral with regard to jurisdictional claims in published maps and institutional affiliations.

Copyright: (C) 2022 by the authors. Licensee MDPI, Basel, Switzerland. This article is an open access article distributed under the terms and conditions of the Creative Commons Attribution (CC BY) license (https:// creativecommons.org/licenses/by/ $4.0 /)$.

\begin{abstract}
Larix principis-rupprechtii is an important afforestation tree species in the North China alpine coniferous forest belt. Studying the correlations and response relationships between Larix principisrupprechtii radial growth and climatic factors at different elevations is helpful for understanding the growth trends of L. principis-rupprechtiind its long-term sensitivity and adaptability to climate change. Pearson correlation, redundancy (RDA), and sliding analysis were performed to study the correlations and dynamic relationships between radial growth and climatic factors. The main conclusions are as follows: (1) The three-elevation standard chronologies all exhibited high characteristic values, contained rich climate information and were suitable for tree-ring climatological analyses. (2) Both temperature and precipitation restricted low-elevation L. principis-rupprechtii radial growth, while monthly maximum temperatures mainly affected mid-high-elevation L. principis-rupprechtii radial growth. (3) Mid-elevation L. principis-rupprechtii radial growth responded to climate factors with a "lag effect" and was not restricted by spring and early summer drought. (4) Long-term sliding analysis showed that spring temperatures and winter precipitation were the main climatic factors restricting L. principis-rupprechtii growth under warming and drying climate trends at different elevations. The tree-ring width index and Palmer drought severity index (PDSI) were positively correlated, indicating that L. principis-rupprechtii growth is somewhat restricted by drought. These results provide a reference and guidance for L. principis-rupprechtii management and sustainable development in different regions under warming and drying background climate trends.
\end{abstract}

Keywords: dendroclimatology; tree-ring width; elevational gradient; climate change

\section{Introduction}

Climate conditions affect forest ecosystems in terrestrial, aquatic, and marine environments. Forest ecosystems in terrestrial environments are closely related to climate conditions. In most cases, climatic factors do not exert the main control on the development of tree productivity [1,2], but the inherent growth and development of forest ecosystems are intrinsically linked to climate change $[3,4]$. Regional subalpine forest ecosystems exhibit more sensitive responses to climate change than other forest ecosystems [5], and alpine forest line ecotones are physiologically limited habitats that are also sensitive to climate change [6,7], showing obvious responses to past climate change processes. Tree-ring data have the natural advantages of facilitating accurate dating, sensitivity to climate change, high resolution, and easily accessible samples. Therefore, many scholars choose to use tree rings to indicate climate change trends $[8,9]$. Based on wide or narrow changes between tree rings, we can accurately understand the yearly growth statuses of trees and the responses of tree growth to climate and site condition changes [10-12]. 
In the field of tree-ring climatology, the responses of the annual tree-ring width index and climatic factors differ under different habitat conditions, and the corresponding response mechanisms also differ [13]. Generally, the main factor limiting the growth of high-elevation trees is temperature, and the main limiting factors affecting low-elevation trees are precipitation and temperature [14-17]. However, due to the different geographical locations of trees, differences in local topography and climate affect the main climatic factors that limit tree growth [18-22], resulting in geographical differentiation [23,24]. In this paper, a variety of meteorological indicators are selected to explore the differences in the main meteorological factors that restrict forest growth among different elevations throughout the Guancen Mountain area.

The Lvliang Mountains are a north-south-oriented mountain range in the western part of Shanxi Province. The range is approximately $400 \mathrm{~km}$ long from north to south and $100 \mathrm{~km}$ wide from east to west. The mountains are higher in the north and lower in the south, with overall elevations below $3000 \mathrm{~m}$. This area is a natural geographic boundary delineating the watershed between the Yellow River and the Fen River [25,26]. To the west is a typical loess plateau area, and to the east is the intermittent transition zone between the Loess Plateau and the North China Plain. The sampling points within the study area considered in this research were selected on Heyeping Mountain, which is the highest peak in the Guancen Mountain group in the northern part of the Lvliang Mountains. Guancen Mountain is roughly located on the precipitation line at which $400 \mathrm{~mm}$ of annual precipitation falls in China and is on the boundary between the temperate monsoon and temperate continental climate zones and the semihumid and semiarid zones [27]. Thus, the study area is located in a transitional and sensitive climate zone suitable for studying tree-ring climatology and represents an ideal research area.

Many studies on the responses of tree radial growth to climatic factors have been conducted at different elevations, exploring the differences in the main climatic factors that limit the radial growth of trees on different altitude gradients. For example, Marín Pompa-García et al. [28] studied the variation in radial growth of Pinus cooperi in response to climatic signals across an elevational gradient; Krishna B et al. [29] studied the growth responses of Abies spectabilis to climate variations along an elevational gradient in Langtang National Park in Central Himalaya, Nepal; and Elena Babushkina et al. [30] studied the divergent growth trends and climatic response of Picea obovata along an elevational gradient in the western Sayan Mountains, Siberia. The response relationships between tree-ring width indexes and climatic factors in different regions and altitudes present different characteristics, and the internal mechanism needs to be explored at multiple points and regions. Near the study area in this article, many scholars have used the principle of tree-ring chronologies to study the responses of tree-ring widths to climatic factors in the subalpine forest line ecotones of northwest Shanxi Province and to reconstruct temperature and precipitation series. For example, Cai Qiufang et al. [31] conducted a study based on tree-ring width samples of Pinus tabuliformis in the central region of the Lvliang Mountains and showed that the radial growth of $P$. tabuliformis is mainly affected by the average temperature from May to July. Li Qiang et al. [32] reconstructed the annual precipitation record in the Ningwu area since 1686 based on $P$. tabuliformis samples collected in the Bagou Bay of Guancen Mountain. Yi Liang et al. [33] analyzed temperature changes from May to July in the Luya Mountain area since 1676 by applying a regional growth model (regional curve standardization, RCS) based on P. tabuliformis samples collected from Luya Mountain. Zhang Wentao et al. [34,35] used L. principis-rupprechtii and Picea meyeri tree-ring width samples collected from the sunny slopes of Luya Mountain to analyze the response relationships between different samples and climatic factors at different elevational gradients. Li Yingjun et al. [36] used L. principis-rupprechtii tree-ring samples collected at different elevations on Luya Mountain to analyze the relationships between tree-ring width index sequences collected at different elevations and climatic factors and between tree-ring width sequences and soil temperatures. 
The aforementioned studies serve as a basis for researching tree-ring climatology in the subalpine forest line ecotones of north-central China. However, there is a lack of comprehensive analysis of the tree-ring width index at different altitudes and various climatic factors in the study area. This study selected L. principis-rupprechtii specimens growing in different elevational gradients on Heyeping Mountain, considered meteorological factors such as monthly extreme temperatures and the Palmer drought severity index (PDSI), and used Pearson correlation, redundancy (RDA), and long-term sliding correlation analysis to explore the correlations and the dynamic long-term relationships between the tree-ring width index and climatic factors in different vertical elevation belts. The objectives of this study were to: (1) develop the ring-width chronologies of L. principis-rupprechtii at different altitudes; (2) analyze whether the same climate factors limit the growth of L. principis-rupprechtii at different altitudes; (3) and detect the dynamic long-term relationships between the tree-ring width index and climatic factors at different altitudes. Under warming and drying climate trends, this study provides a scientific reference and basis for cultivating forests at different elevations and provides additional professional and systematic indicators for forest management and cultivation on Guancen Mountain and in north-central Chinese provinces.

\section{Materials and Methods}

\subsection{Overview of the Study Area}

Guancen Mountain is located in the northwestern region of Shanxi Province and is geographically located between $38^{\circ} 36^{\prime} \mathrm{N}$ and $39^{\circ} 02^{\prime} \mathrm{N}$ and between $111^{\circ} 46^{\prime} \mathrm{E}$ and $112^{\circ} 54^{\prime} \mathrm{E}$. The terrain has a large elevation difference and is the birthplace of the Fen River, which is the second largest tributary of the Yellow River. The Guancen Mountain forest area preserves a large number of virgin forest stands and artificial secondary forest stands. It is located in the middle section of the "Three North" shelterbelt system and is the most heavily forested area in North China. The main tree types include L. principis-rupprechtii, Picea, P. tabuliformis, and P. meyeri. The shrub species include thorn plum, tiger hazelnut, sea buckthorn, yellow thorn plum, Sanguisorba, and Cyperus. Vast alpine meadows can also be found in the study area $[37,38]$. Guancen Mountain has a temperate continental monsoon climate. In winter, it is affected by Mongolian-Siberian high pressure with considerable continentality. In summer, it is affected by the warm and humid southeast monsoon, and rainfall is abundant. The combination of the local topography and elevation in this mountainous area makes the local microclimate remarkable. Obvious temperature differences occur between day and night, and heavy fog can be seen on rainy days and in the early morning [39]. The average annual precipitation in the study area is approximately $383 \mathrm{~mm}$, which is mainly concentrated in June-September, accounting for approximately $72 \%$ of the annual precipitation. The annual average temperature is approximately $5.7^{\circ} \mathrm{C}$, and the annual average relative humidity is approximately $57.6 \%$ (Figure 1 ). The vertical zonality of soil and vegetation in the overall study area is significant. Near the $1200-1500 \mathrm{~m}$ elevation range, low mountain shrub areas, farming areas and water areas can be found, with chestnut cinnamon soils and cinnamon soils; near the 1500-1800 m elevation range, low, sparse mountainous forest shrub belts are distributed with leached cinnamon soils; near 1800-2500 $\mathrm{m}$ above sea level, high and middle mountainous coniferous forest belts can be found in brown zonal soils; and near 2500-2784 m above sea level, subalpine meadow belts are present with subalpine meadow zonal soils $[40,41]$. 


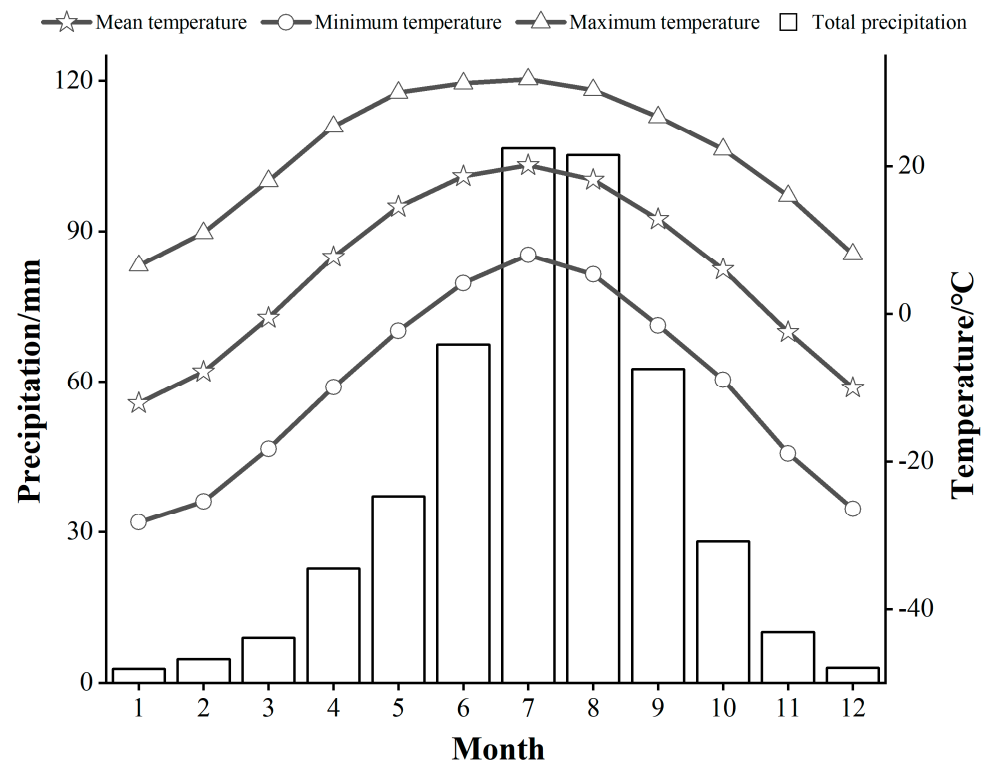

Figure 1. Monthly total precipitation, mean temperature, and maximum and minimum temperature during 1970-2020 using the records from the four meteorological stations, north-central China.

\subsection{Sample Collection and Chronology Establishment}

The L. principis-rupprechtii tree-ring samples used in this study were collected from Heyeping Mountain, which is the highest peak of Guancen Mountain (Figure 2). In July 2021, an area with few human activities within the Guancen Mountain forest area was selected, and samples were obtained from three locations at high, middle, and low elevations (Tables 1 and 2). In accordance with the International Tree Ring Date Bank (ITRDB) standards [42], natural forests with thin soil layers, large slopes, good tree growth, and no pests or diseases were selected for sample collection. During the sampling process, trees with good growth and large diameters at breast height were selected, and an increment borer with an inner diameter of $5.15 \mathrm{~mm}$ was used to collect two sample cores from the measurement positions of the diameter at breast height and the base diameter of the tree, ensuring that the sample cores passed through the pith of the tree and thus provided reliable data sources for the subsequent cross-dating and chronological production processes. The collected sample cores were stored in paper tubes that were numbered in advance to prevent breakage and enable tracking of the sample cores.

Table 1. Information on the three tree-ring sampling points located at different elevations on Guancen Mountain.

\begin{tabular}{ccccccc}
\hline Sampling Site & Latitude & Longitude & Elevation (m) & $\begin{array}{c}\text { Sample Size } \\
\text { (Tree } \backslash \text { Core) }\end{array}$ & $\begin{array}{c}\text { Diameter at Breast } \\
\text { Height (cm) }\end{array}$ & Period \\
\hline HYPA & $38^{\circ} 44^{\prime} 30^{\prime \prime} \mathrm{N}$ & $111^{\circ} 53^{\prime} 32^{\prime \prime} \mathrm{E}$ & 2303 & $24 \backslash 48$ & $43.73 \pm 5.17$ & $1899-2020$ \\
$\mathrm{HYPB}$ & $38^{\circ} 43^{\prime} 46^{\prime \prime} \mathrm{N}$ & $111^{\circ} 52^{\prime} 46^{\prime \prime} \mathrm{E}$ & 2477 & $23 \backslash 46$ & $39.17 \pm 3.55$ & $1914-2020$ \\
$\mathrm{HYPC}$ & $38^{\circ} 43^{\prime} 45^{\prime \prime} \mathrm{N}$ & $111^{\circ} 52^{\prime} 13^{\prime \prime} \mathrm{E}$ & 2539 & $23 \backslash 46$ & $42.25 \pm 4.44$ & $1919-2020$ \\
\hline
\end{tabular}

The ${ }^{*}$ symbol represents the mean \pm standard error.

Table 2. Information about the sampling sites of L. principis-rupprechtii.

\begin{tabular}{cccccccc}
\hline Sampling Site & Elevation $(\mathbf{m})$ & Slope Steepness $\left(^{\circ}\right)$ & Slope Aspect $\left(^{\circ}\right)$ & Soil & $\begin{array}{c}\text { Canopy } \\
\text { Availability }\end{array}$ & $\begin{array}{c}\text { Air Pressure } \\
(\mathbf{k p a})\end{array}$ \\
\hline HYPA & 2303 & 27 & West by north 36 & $\begin{array}{c}\text { Leached } \\
\text { cinnamon, } \\
\text { Brown earth }\end{array}$ & 0.6 & 77.36 \\
\hline HYPB & 2477 & 13 & East by south 72 & Brown earth & 0.7 & 74.98 \\
\hline HYPC & 2539 & 65 & West by north 5 & Brown earth & 0.4 & 74.42 \\
\hline
\end{tabular}



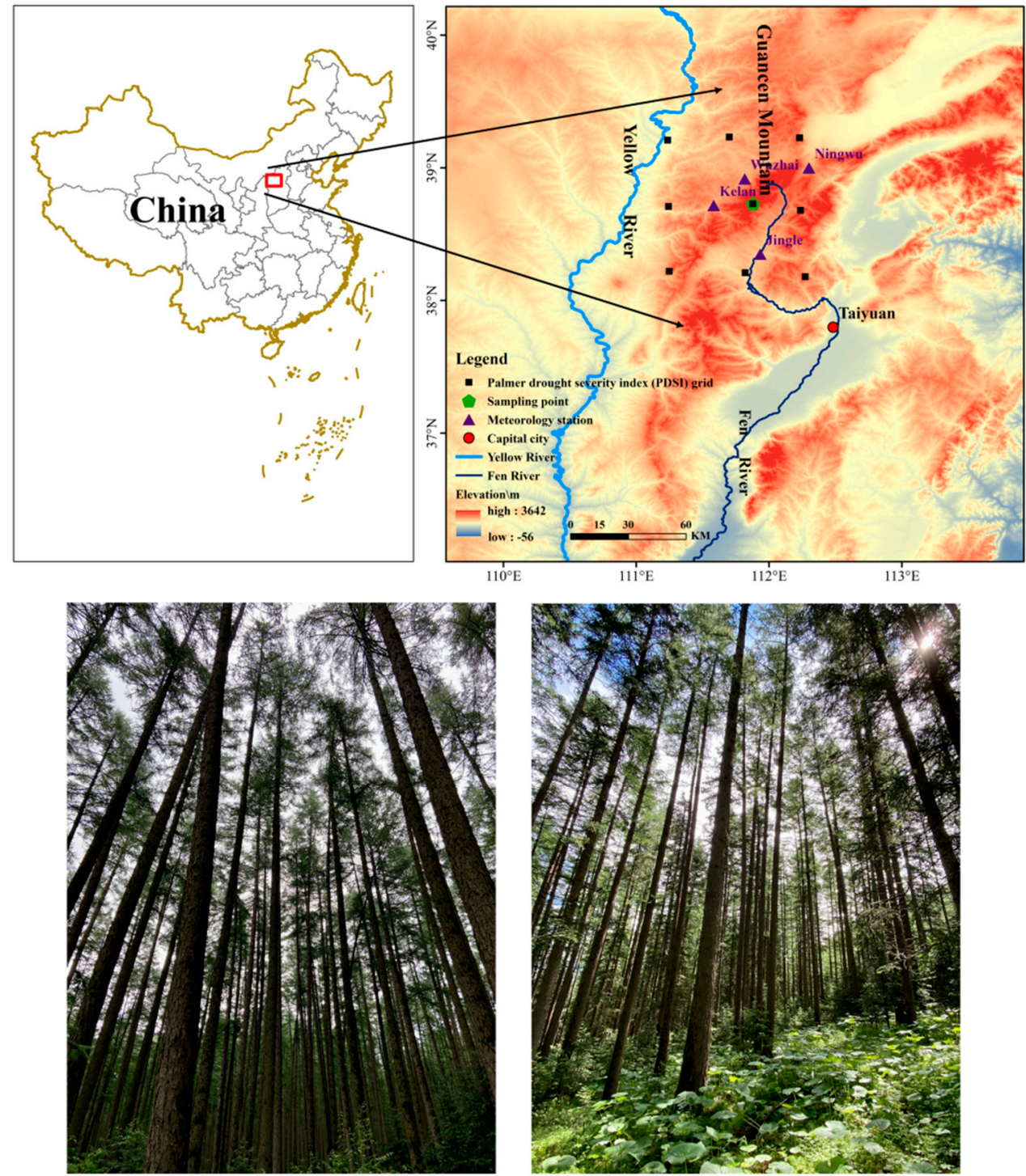

Figure 2. Locations of the L. principis-rupprechtii tree-ring sampling point and weather stations on Guancen Mountain.

The sample cores were brought back to the laboratory, and splitting and pretreatment were carried out according to the basic methods outlined by Stokes and Smiley [43]. Each sample core was placed into a wooden trough, and the specific information of the sample core was recorded. After the wood glue air-dried, each sample core was sanded with 320-, $600-$, and 800-mesh sandpaper in turn until the annual rings were clearly visible. Under a binocular microscope, visual cross-dating was carried out using the skeleton diagram method to preliminarily determine the growth periods experienced by the tree. Each sample core was cross-dated $[8,44]$, and the annual tree-ring width was then measured with a LinTab ${ }^{\mathrm{TM}} 6$ instrument (Rinntech, Heidelberg, Germany) at an accuracy of $0.001 \mathrm{~mm}$. The COFECHA program [45] was used to inspect the dating and measurement results. Sample cores with incorrect dates or large errors were detected, and dating and width measurements were performed again to ensure that the sample cores were measured with high accuracies. Then, samples that were poorly correlated with the main sequence or difficult to cross-date were eliminated, and the remaining samples were used to establish the chronology [46].

In this study, the linear function and negative exponential function in the ARSTAN program [47] were used to fit the tree growth trends [48], thereby eliminating the influence of nonclimatic factors. In the detrending process, we consistently applied different window 
sizes to further accurately and effectively determine the common interval. For the chronologies of the three elevation sampling points derived in this paper, 10-year effective windows and 5-year overlapping areas were adopted. The annual ring curves were standardized by the double-weighted average method to eliminate the influence of physiological characteristics and site environmental conditions on tree growth [48]. Finally, L. principis-rupprechtii tree-ring chronologies representing the three elevations were established. After comparing the statistical characteristic values of the standard chronology (STD), residual chronology (RES), and arstan chronology (ARS), the STD value, which showed the most high- and low-frequency signals [49] and best resulting chronological quality, was selected to analyze the relationships between tree rings and climate conditions (Figure 3).
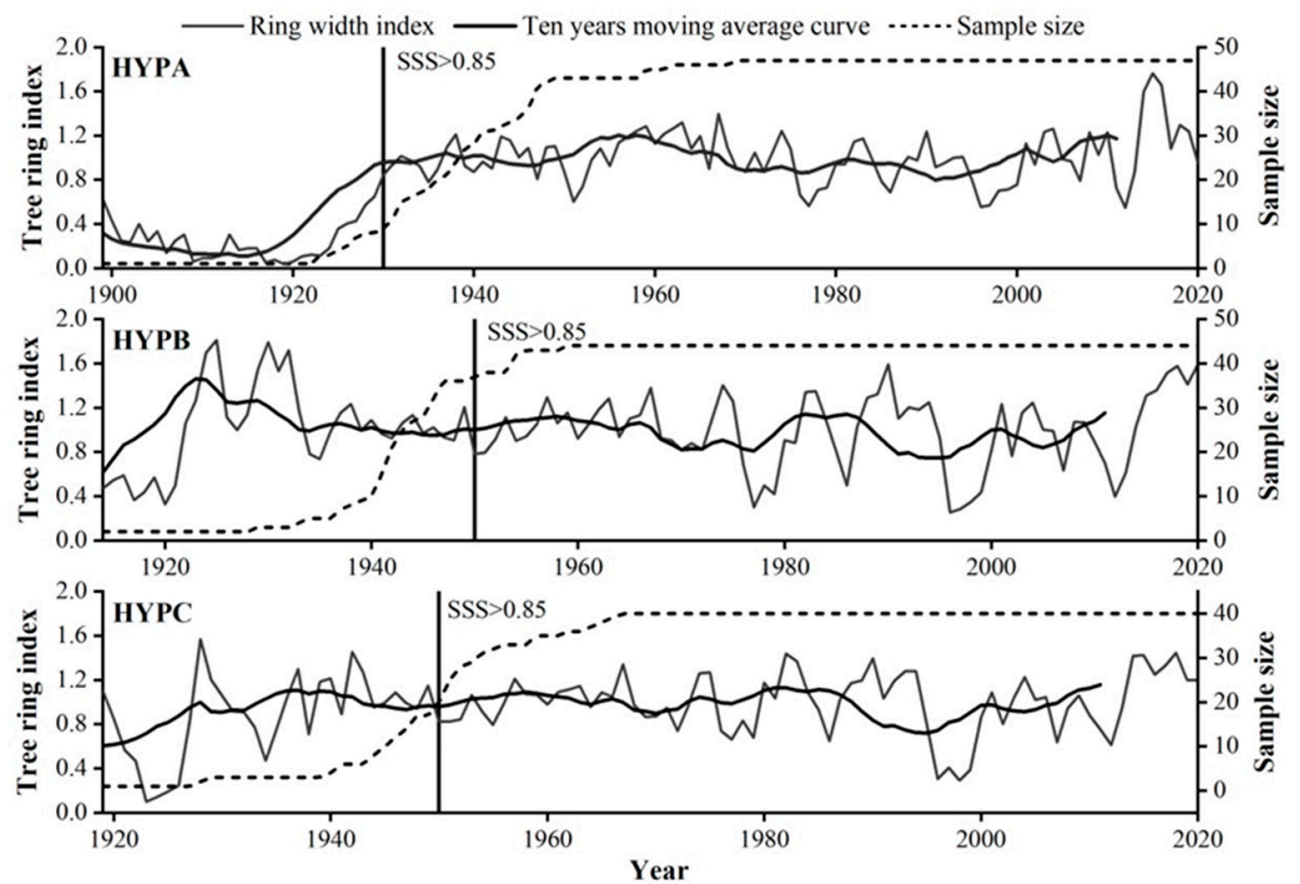

Figure 3. Standard chronologies and sample sizes of the annual ring widths of L. principis-rupprechtii trees growing at different elevations on Guancen Mountain.

\subsection{Meteorological Data Collection and Processing}

Meteorological station data were obtained from the China National Meteorological Science Data Center (http: / / data.cma.cn / accessed on 15 September 2021). The meteorological data were selected from the four weather stations located closest to the sampling point, namely, the Ningwu Weather Station $\left(39^{\circ} 00^{\prime} \mathrm{N}, 112^{\circ} 18^{\prime} \mathrm{E}\right.$; elevation of $\left.1437.4 \mathrm{~m}\right)$, Kelan Weather Station $\left(38^{\circ} 43^{\prime} \mathrm{N}, 111^{\circ} 35^{\prime} \mathrm{E}\right.$; elevation of $\left.1396.7 \mathrm{~m}\right)$, Wuzhai Weather Station $\left(38^{\circ} 55^{\prime} \mathrm{N}, 111^{\circ} 49^{\prime} \mathrm{E}\right.$; elevation of $\left.1401.0 \mathrm{~m}\right)$, and Jingle Weather Station $\left(38^{\circ} 21^{\prime} \mathrm{N}, 111^{\circ} 56^{\prime} \mathrm{E}\right.$; elevation of $1212.2 \mathrm{~m}$ ). This study mainly used the monthly maximum temperature (Tmax), monthly minimum temperature (Tmin), monthly mean temperature (MT), monthly precipitation (PRE), and PDSI [50] as the 5 considered meteorological indicators from 1970 to 2020 .

The PDSI grid point data derived from the study area and the collected relevant site, soil, and runoff data were based on the meteorological data provided by the National Meteorological Science Data Center. According to the three principles of drought records, the geographical distribution of the data, and the comprehensiveness of the climate data, the PDSI values were calculated using a Python code. The PDSI calculation process was divided into five main parts: (1) the accounting of hydrological statistics; (2) the calculation of various climate indexes; (3) the calculation of various climate suitability components; (4) the calculation of the water surplus/deficiency value (s) and water anomaly index (z); (5) and the calculation of a specific value with the PDSI formula [51,52]. Nine grid points 
$\left(38.73^{\circ} \mathrm{N}, 111.88^{\circ} \mathrm{E} ; 38.71^{\circ} \mathrm{N}, 111.24^{\circ} \mathrm{E} ; 38.68^{\circ} \mathrm{N}, 112.24^{\circ} \mathrm{E} ; 39.23^{\circ} \mathrm{N}, 112.23^{\circ} \mathrm{E} ; 39.23^{\circ}\right.$ $\mathrm{N}, 111.70^{\circ} \mathrm{E} ; 39.21^{\circ} \mathrm{N}, 111.24^{\circ} \mathrm{E} ; 38.22^{\circ} \mathrm{N}, 111.25^{\circ} \mathrm{E} ; 38.21^{\circ} \mathrm{N}, 111.82^{\circ} \mathrm{E}$; and $38.18^{\circ} \mathrm{N}$, $112.27^{\circ} \mathrm{E}$ ) were selected around the sampling area, which were used with Arcmap 10.2 multivalue extraction to obtain a point average and calculate the specific PDSI values (Figure 4).

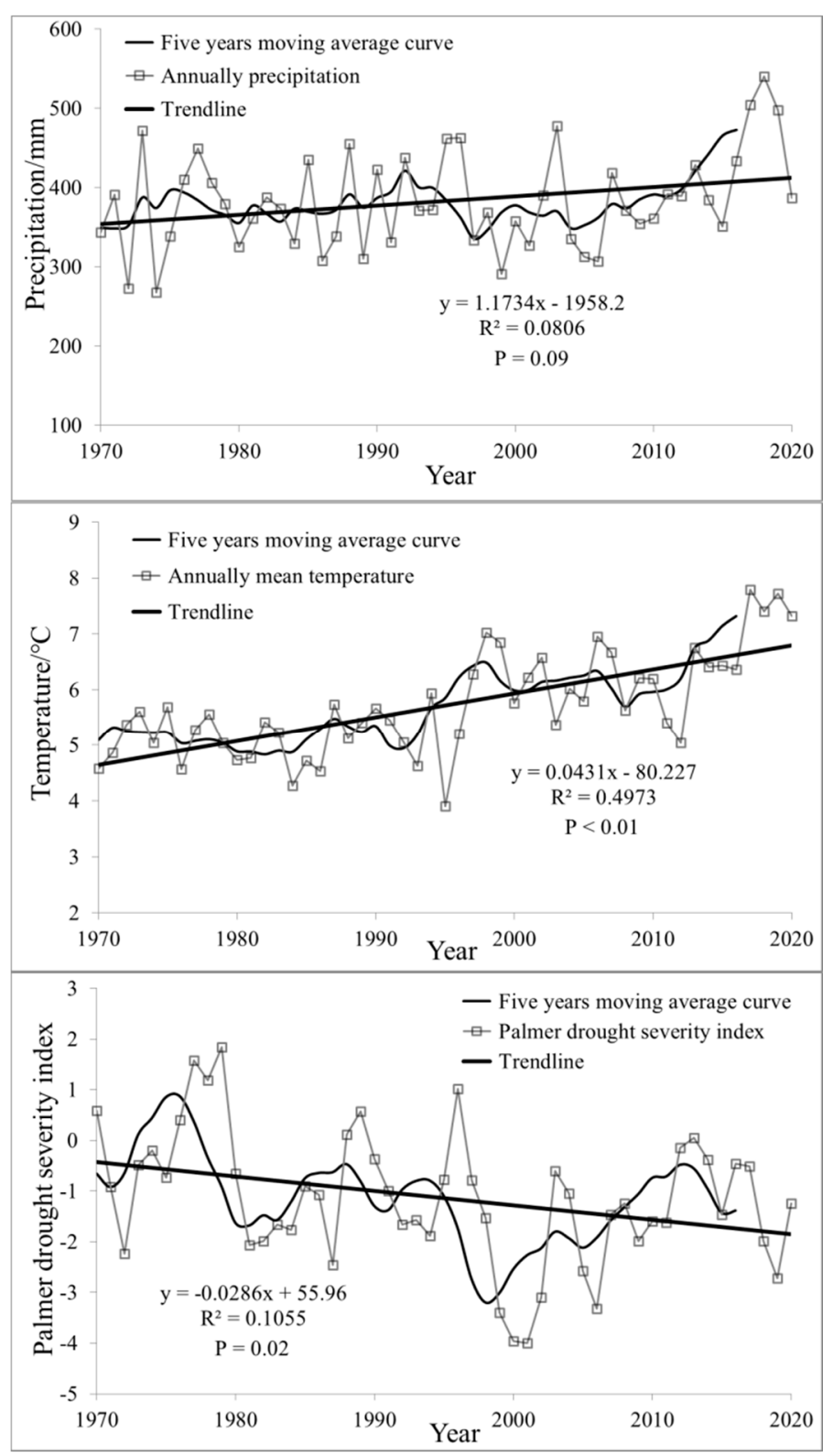

Figure 4. Annual change trends of precipitation and average temperature at 4 meteorological stations and the PDSI values near the sampling points from 1970 to 2020.

\subsection{Data Analysis}

To analyze the differences in the main climatic factors affecting the radial growth of L. principis-rupprechtii at different elevations, the Pearson correlation analysis method was utilized in SPSS software to analyze the correlations between the tree-ring width index and different meteorological indicators. RDA analysis was performed in CANOCO 5.0 software to further verify the relationships between the radial growth of L. principis-rupprechtii and climate factors at different elevations. RDA analysis is a multivariate environmental gradient analysis method in which the relationships between the radial growth of trees and climate factors are evaluated by regression and principal component analyses of the tree- 
ring width chronologies and climate variables [53]. Through this method, the relationships between the tree-ring width index and meteorological factors can be quantitatively analyzed with relatively high accuracy [54]. The sliding correlation function in the DendroClim 2002 program was used to analyze the dynamic relationships between tree-ring chronologies and climatic factor responses over time (the sliding window was set to 26 years) [55].

Taking into account the "lag phenomenon" of tree growth in response to climatic factors, tree growth in a given year is affected not only by climatic factors during the current growing season but also by changes in climatic factors that occurred during the growing season of the previous year, and changes that occur later in the growing season also affect the growth and development of trees. Therefore, meteorological index data representing a total of 19 months from June of the previous year to December of the current year were selected for the correlation analysis and multiple regression analysis.

In the detrending and standardization processes applied to the tree-ring width index chronologies, the ARSTAN program eliminated the growth trends of the trees but could not objectively express the changes in tree growth that occurred each year. To a certain extent, measuring the basal area increment (BAI) at breast diameter of trees can objectively represent the annual growth changes experienced by trees (Figure 5). The tree-ring BAI at breast height was calculated according to the following formula:

$$
\mathrm{BAI}_{\mathrm{n}}=\pi\left(\mathrm{d}_{\mathrm{n}}^{2}-\mathrm{d}_{\mathrm{n}-1}^{2}\right)
$$

where $d$ represents the radius of the tree (the unstandardized original tree-ring width value) and $\mathrm{n}$ represents the year of tree-ring formation [56].

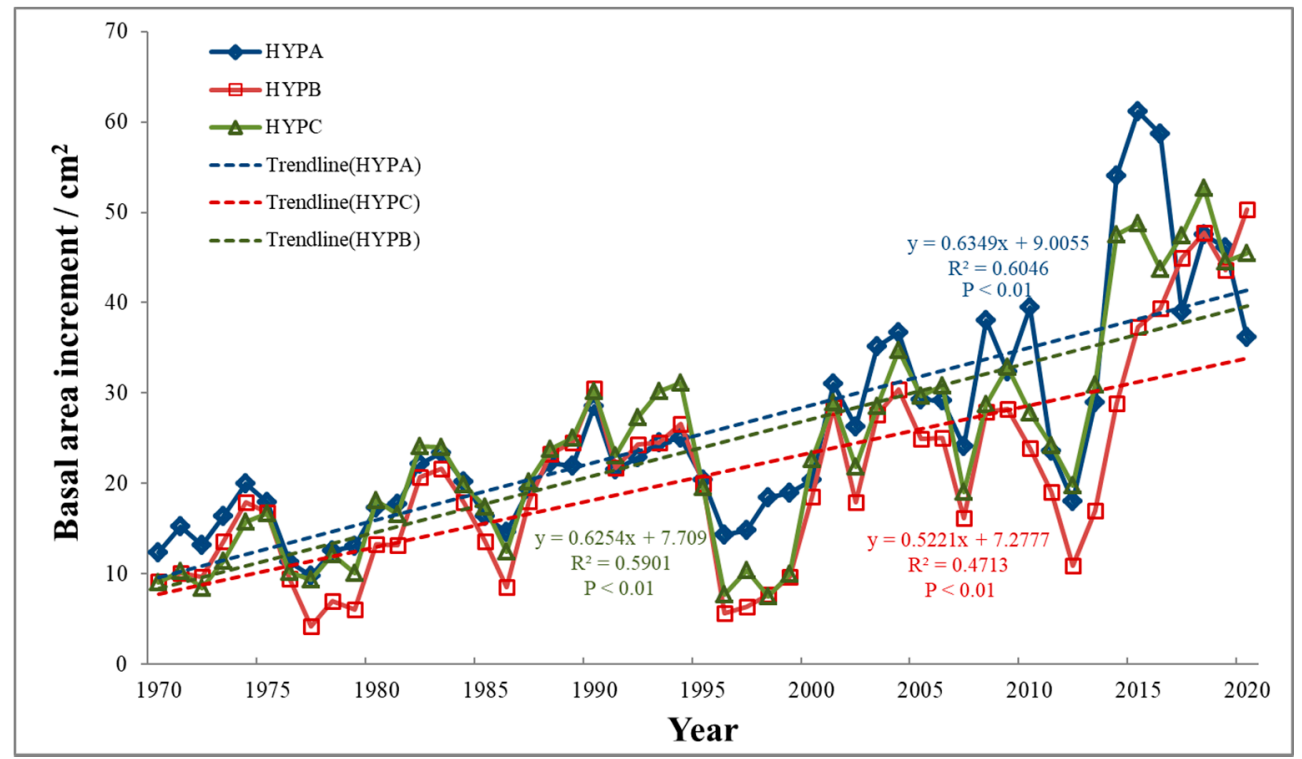

Figure 5. Basal area increments of L. principis-rupprechtii at different elevations on Guancen Mountain.

\section{Results}

\subsection{Chronological Characteristics Analysis}

From the statistical analysis of the tree-ring chronologies obtained from trees at the three sampling points (Table 3), it can be seen that the standard deviation ranged between 0.3 and 0.4 , and the mean interseries correlation coefficients of the tree rings at the three sampling points were obviously different, indicating that the chronologies obtained at different elevations had good regional consistency and could represent the average growth status of L. principis-rupprechtii specimens at different elevations on Guancen Mountain. The high correlation coefficients between the sample cores (R1, R2 and R3) indicated that the sample cores at the sampling point had better consistency. The mean sensitivity ranged from $0.23-0.25$, and the signal-to-noise ratio was as low as 5 and as high as 64 , indicating 
that the standard chronology at each sampled elevation retained a significant amount of climate information. The expressed population signals of the samples were close to or far exceeded the threshold of 0.85 [57], indicating that the above three chronological datasets could represent the basic change characteristics of $L$. principis-rupprechtii tree-ring widths in the study area well. The first-order serial autocorrelation coefficients all exceeded 0.63 , indicating that the radial growth of trees in one year was affected by the climatic conditions in the previous year and revealing a certain lag effect [58].

Table 3. Statistical information of the standard L. principis-rupprechtii tree-ring chronologies at different elevations on Guancen Mountain.

\begin{tabular}{cccc}
\hline Sampling Site & HYPA & HYPB & HYPC \\
\hline Common interval & $1930-2020$ & $1950-2020$ & $1950-2020$ \\
SD & 0.397 & 0.351 & 0.305 \\
MS & 0.237 & 0.240 & 0.245 \\
r & 0.882 & 0.690 & 0.640 \\
AC1 & 0.875 & 0.684 & 0.634 \\
R1 & 0.376 & 0.634 & 0.638 \\
R2 & 0.350 & 0.650 & 0.748 \\
R3 & 0.385 & 0.631 & 0.596 \\
SNR & 5.427 & 64.163 & 35.217 \\
EPS & 0.844 & 0.985 & 0.972
\end{tabular}

SD: standard deviation; MS: mean sensitivity; r: mean interseries correlation; AC1: first-order serial autocorrelation; R1: all-series mean correlation; R2: within-trees mean correlation; R3: between-trees mean correlation; SNR: signal-to-noise ratio; and EPS: expressed population signal.

The chronologies of the three sampling points described above conform to these basic characteristics of high-quality chronologies, and all obtained chronologies have a certain sensitivity to climate conditions and thus are suitable for studying tree-ring climatology. The mean sensitivities and signal-to-noise ratios of the mid- and high-elevation chronologies were higher than those of the low-elevation chronology, indicating that the responses of the mid- and high-elevation regions to climate conditions were more sensitive and significant than those of the low-elevation regions. Compared with the low-elevation area, the expressed population signals of the samples at middle and high elevations were as high as 0.95 or greater, indicating that the mid- and high-elevation standard chronology data could represent the overall characteristics of the respective regions better than the lowelevation standard chronology data. Generally, the climate-factor sensitivity and regional representativeness of the mid- and high-elevation chronologies were better than those of the low-elevation chronology (Table 4).

Table 4. Correlation coefficients between the standard chronologies at the sampling points.

\begin{tabular}{cccc}
\hline Sampling Site & HYPA & HYPB & HYPC \\
\hline HYPA & 1 & - & - \\
HYPB & $0.666^{* *}$ & 1 & - \\
HYPC & $0.651^{* *}$ & $0.745^{* *}$ & 1 \\
\hline
\end{tabular}

The ${ }^{\text {** }}$ symbol represents a significant correlation at the 0.01 level.

\subsection{Correlation Analysis of the L. principis-rupprechtii Chronologies and Monthly Climatic Factors at Different Elevations}

The correlation analysis results of the tree-ring width chronologies sampled at different elevations and monthly mean temperatures show that the chronologies representing the three elevations were mainly affected by the monthly mean temperature at the beginning of the growing season of the current year. The low-elevation chronology was significantly positively correlated with the mean temperatures in January, March, April, and November of the considered year $(\mathrm{r}>0.25, p<0.05)$. The mid-elevation chronology was significantly positively correlated with the mean temperatures in May and November of the considered 
year $(r>0.25, p<0.05)$. The high-elevation chronology had a certain correlation with the mean temperature, but no monthly temperatures reached a significant correlation level (Figure 6).

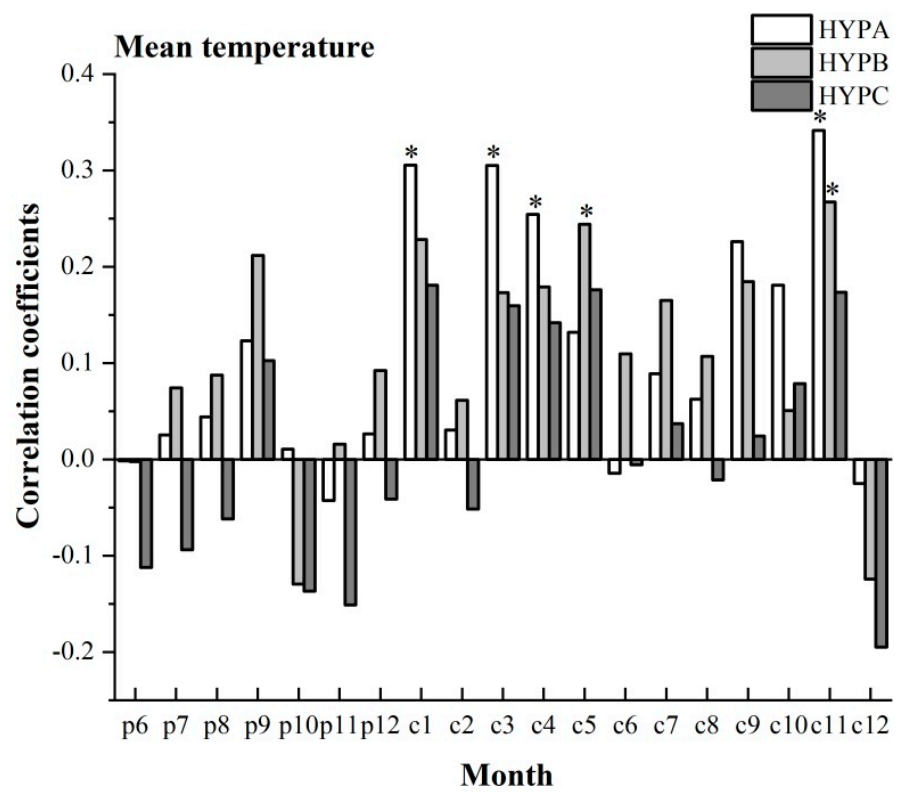

Figure 6. Correlations between the chronology of L. principis-rupprechtii tree rings and the monthly mean temperature at different elevations ( $p$ represents the previous year; $c$ represents the current year; and the * symbol represents a significant correlation at the 0.05 level).

The low-elevation tree-ring width chronology was significantly positively correlated with the minimum temperatures in June of the previous year and April of the current year $(\mathrm{r}>0.28, p<0.05)$, the mid-elevation chronology was significantly negatively correlated with the minimum temperatures in July of the current year $(r=-0.27, p<0.05)$, and the high-elevation chronology exhibited only a certain nonsignificant correlation with the minimum temperature. The low-elevation tree-ring width index chronology was significantly positively correlated with the maximum temperatures in January and March of the current year $(r>0.30, p<0.05)$, and the mid-elevation chronology was significantly positively correlated with the maximum temperatures in July and August of the previous year and January, March, April, May, June, July, August, and November of the current year $(\mathrm{r}>0.30, p<0.05)$. These temperatures comprised almost the entire growing season of midelevation L. principis-rupprechtii. The correlation between the high-elevation chronology and the monthly maximum temperature was similar to the described response of the midelevation chronology, especially for January, March, April, and May. The radial growth of L. principis-rupprechtii trees at mid-elevation was significantly affected by the monthly maximum temperature (Figure 7).

The low-elevation tree-ring width index chronology was significantly positively correlated with precipitation in January and February of the considered year $(\mathrm{r}>0.25, p<0.05)$. The mid-elevation tree-ring width chronology was significantly negatively correlated with the precipitation in September of the previous year $(\mathrm{r}=-0.26, p<0.05)$ and significantly positively correlated with the precipitation in January of the current year $(\mathrm{r}=0.32, p<0.05)$. The high-elevation tree-ring width chronology did not exhibit any significant correlation with monthly precipitation. The Pearson correlation analysis results obtained for the treering width chronologies at different elevations and the PDSI values indicated no significant correlation between the low- or high-elevation chronology indexes and the PDSI values. The mid-elevation tree-ring width chronology was significantly negatively correlated with the PDSI value in September of the previous year and the PDSI values in March, May, and 
June of the current year $(\mathrm{r}<-0.25, p<0.05)$. The high-elevation chronology was positively correlated with the PDSI value in June of the previous year $(\mathrm{r}=0.18)$ (Figure 8$)$.
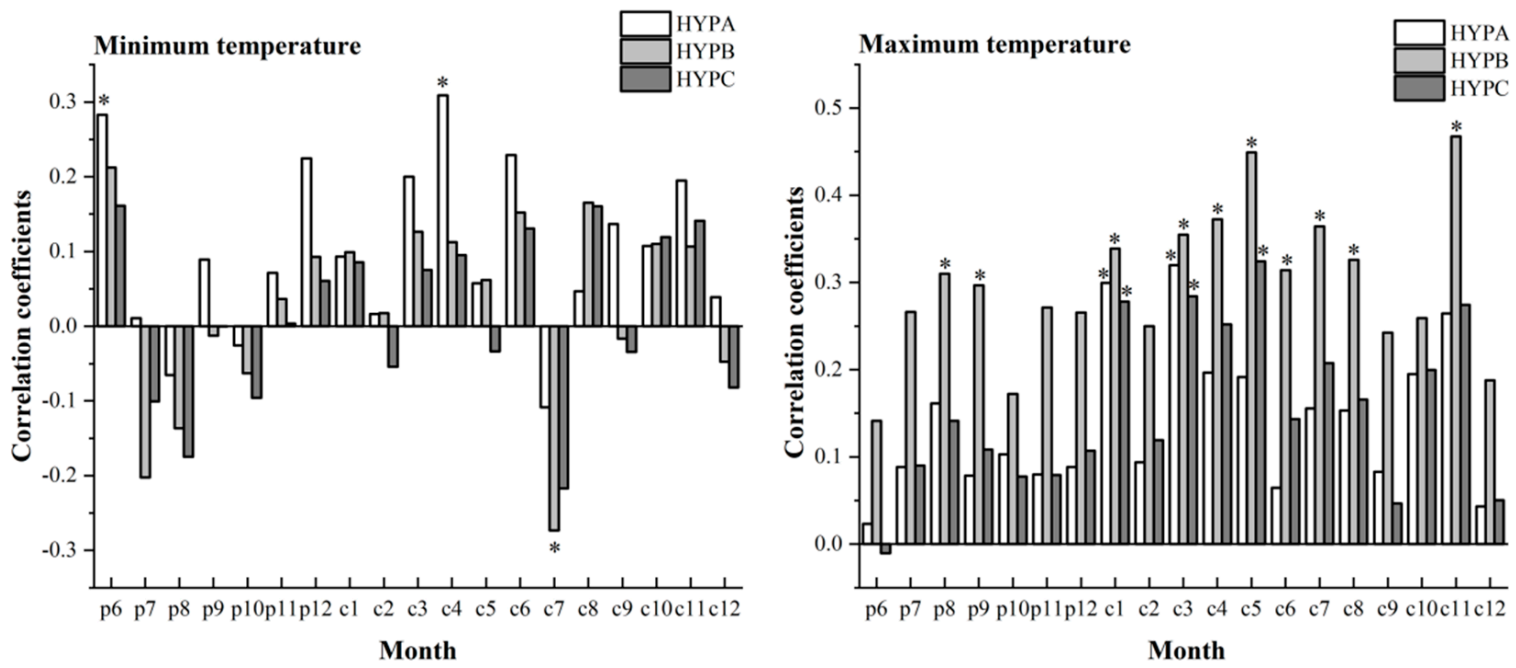

Figure 7. Correlations between the L. principis-rupprechtii tree-ring chronologies and the monthly minimum and maximum temperatures at different elevations ( $p$ represents the previous year; $c$ represents the current year; and the * symbol represents a significant correlation at the 0.05 level).
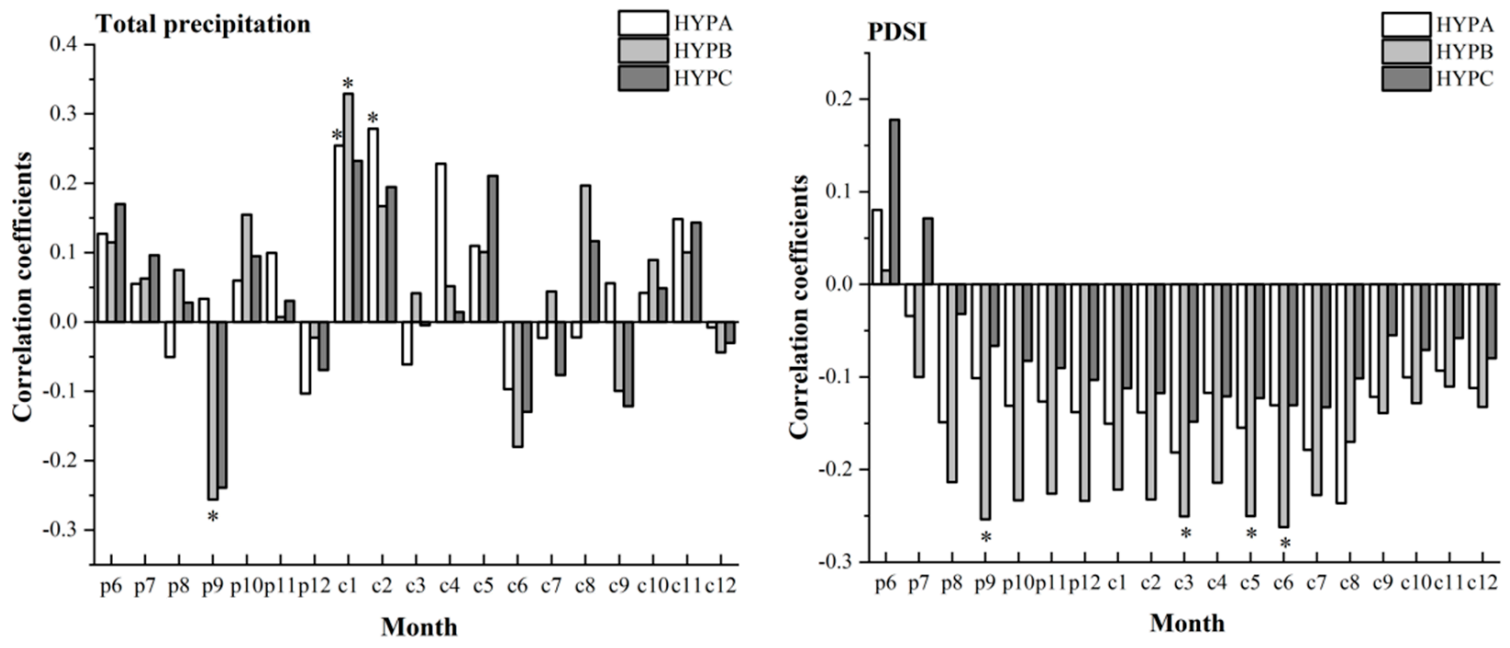

Figure 8. Correlations between the L. principis-rupprechtii tree-ring chronologies and the monthly precipitation and between the chronologies and the PDSI values ( $p$ represents the previous year; $c$ represents the current year; and the * symbol represents a significant correlation at the 0.05 level).

\subsection{Redundancy Analysis of the L. principis-rupprechtii Chronologies and Climatic Factors at Different Elevations}

Figure 9 shows only the significant climate factors $(p<0.05)$. The longer the vector is, the more important the climate factor is, and the more significant the impact of the factor on the chronology is. The cosine of the angle between the climate factor and the chronology vector represents the correlation coefficient between the chronology and the climate factor. Two vectors pointing in the same direction indicate a positive correlation; two vectors pointing in opposite directions indicate a negative correlation; and two vectors pointing in the vertical direction indicate that the two vectors are not related $[59,60]$.

Ninety-five climatic variables recorded from 1971 to 2020 (monthly mean temperatures, monthly minimum temperatures, monthly maximum temperatures, monthly precipitations, and PDSI values from June of the previous year to December of the current year) and treering width indexes sampled at different elevations were selected for RDA analysis. The 
RDA analysis results of the tree-ring width index chronologies and temperature factors showed that the mean temperatures in March and November of the current year were significantly positively correlated with the tree-ring width index value obtained for the low-elevation sampling point; the maximum temperature in May of the current year was significantly positively correlated with the mid-high-elevation tree-ring width index values; the minimum temperatures in June of the previous year and April of the current year were significantly positively correlated with the low-elevation tree-ring width index value; and the minimum temperature in July of the current year was significantly negatively correlated with the mid-elevation tree-ring width index value. The RDA analysis results of the treering width index chronologies and humidity factors showed that the precipitation amounts in January and February of the current year were significantly positively correlated with the low-elevation tree-ring width index, while the precipitation in September of the previous year and the mid-elevation tree-ring width index were significantly negatively correlated. The mid-elevation tree-ring width index was also significantly negatively correlated with the PDSI values in September of the previous year and June of the current year, while the high-elevation tree-ring width index was positively correlated with the PDSI in June of the previous year. Thus, to a certain extent, the radial growth of L. principis-rupprechtii is restricted by drought at high elevations.
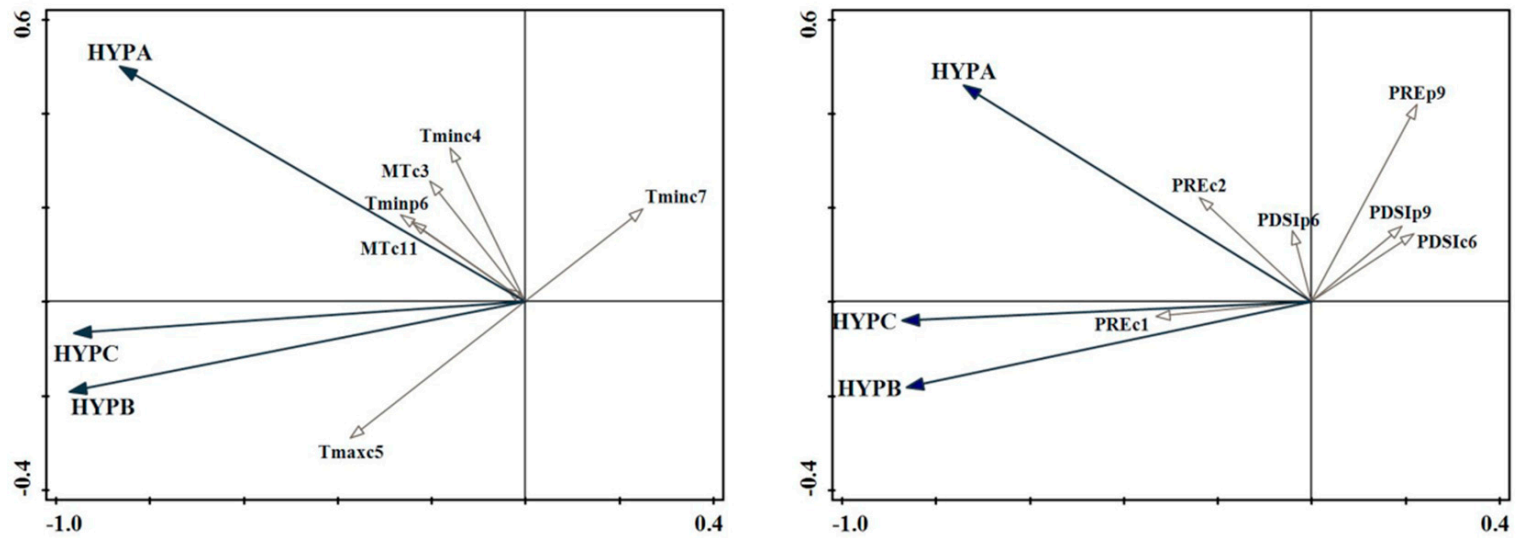

Figure 9. Redundancy analysis of the standard L. principis-rupprechtii chronologies (thick solid line) and monthly climatic factors (thin solid line) at different elevations (1971-2020). HYPA: standard chronology for low-elevation L. principis-rupprechtii; HYPB: standard chronology for mid-elevation L. principis-rupprechtii; HYPC: standard chronology for high-elevation L. principis-rupprechtii; MT: monthly mean temperature; Tmin: monthly minimum temperature; Tmax: monthly maximum temperature; PRE: monthly total precipitation; and PDSI: Palmer drought severity index ( $p$ represents the previous year; c represents the current year).

The RDA analysis results obtained for the standard L. principis-rupprechtii tree-ring chronologies and temperature and humidity variables among 3 elevational gradients showed that for temperature, the first and second axes explained $96.82 \%$ of variation in the response variable, with the first axis explaining $89 \%$ and the second axis explaining $7.82 \%$. For humidity, the first and second axes together explained $76.94 \%$ of variation in the response variable, with the first axis explaining $70.29 \%$ and the second axis explaining $6.65 \%$. These results showed that the radial growth of L. principis-rupprechtii at different elevations on Guancen Mountain was relatively consistent with the influence of climate change. Temperature and humidity were the main climatic factors affecting the radial growth of L. principis-rupprechtii at different elevations on Guancen Mountain. The main factor affecting the radial growth of L. principis-rupprechtii at middle and high elevations was temperature, while at low elevations, the radial growth of L. principis-rupprechtii was restricted by both temperature and humidity conditions. The RDA and correlation analysis results obtained for the standard chronology width index and climatic factors were basically consistent among different elevations. 
3.4. Dynamic Relationships between the L. principis-rupprechtii Chronologies and Climatic Factors at Different Elevations

The radial growth of L. principis-rupprechtii trees at different elevations on Guancen Mountain is affected by temperature, precipitation, and the drought index, but the limiting factors differ among different elevations. In the sliding analysis of the tree-ring width index results obtained for L. principis-rupprechtii trees growing at different elevations and the three climatic factors measured from October of the previous year to October of the current year, a sliding window of 26 years was selected to analyze the long-term dynamics of the tree-ring width index and climatic factors. Over time, the tree-ring width index values obtained at middle and high elevations were first negatively correlated and then significantly positively correlated with the mean temperature in spring. Regarding longterm trends, the tree-ring width index values derived at high, middle and low elevations were significantly positively correlated with the precipitation amounts measured in January and February $(\mathrm{r}>0.30, p<0.05)$, with mid-elevation tree rings showing the most obvious correlation. The correlations between the tree-ring width index values derived at high, middle and low elevations and the PDSI transitioned from significantly negative to positive, and the correlations were particularly obvious at low and high elevations. The sliding analysis results obtained for the tree-ring width index values and climatic factors were similar to the results obtained from the correlation and RDA analysis and conformed to the overall growth trends of trees in response to climate change under warming and drying climate trends (Figures 10-12).
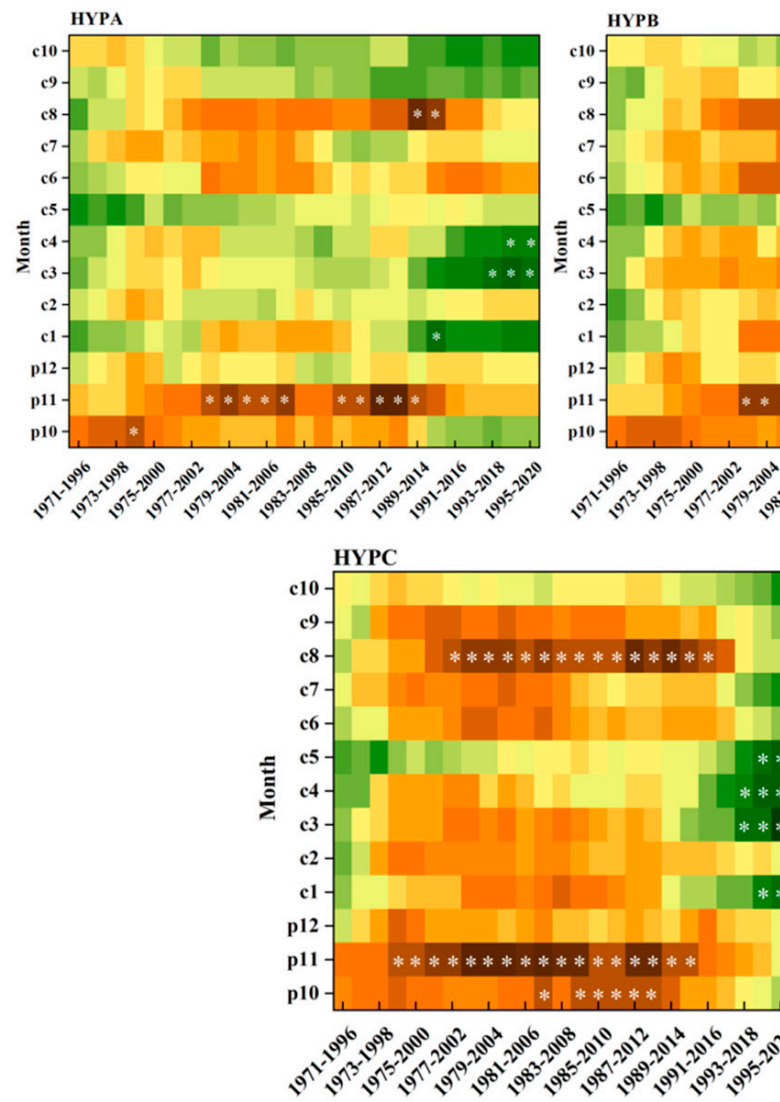
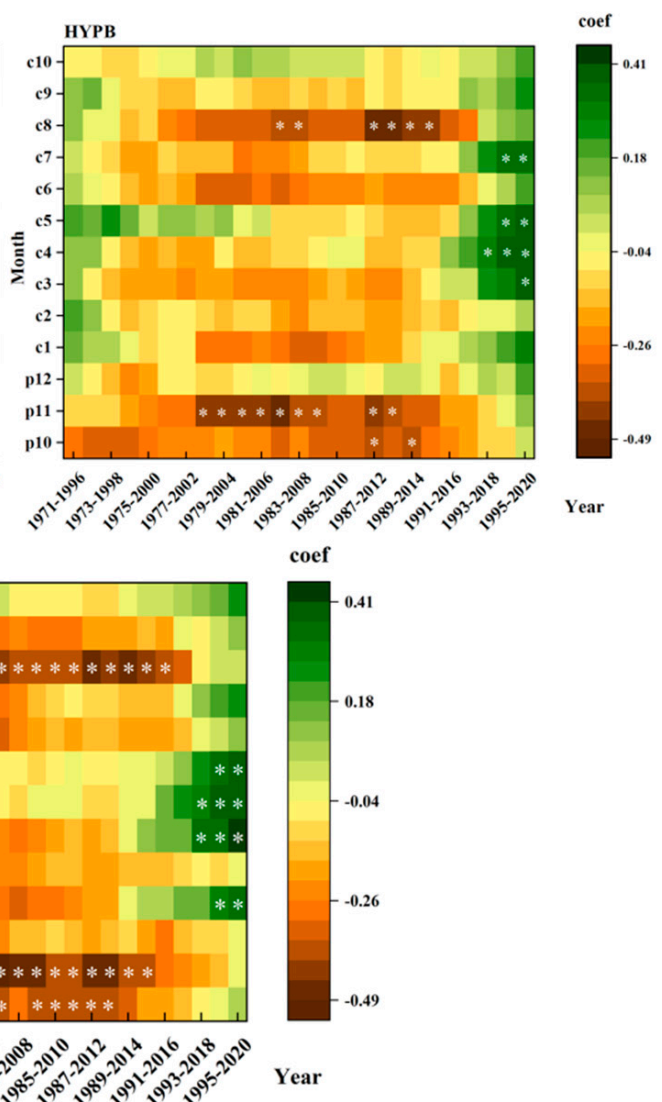

Figure 10. Sliding analysis results of the L. principis-rupprechtii tree-ring width index values derived at different elevations and the mean temperature from October of the previous year to October of the current year (with a sliding window of 26 years; $p$ represents the previous year; $c$ represents the current year; and the * symbol represents a significant correlation at the 0.05 level). 

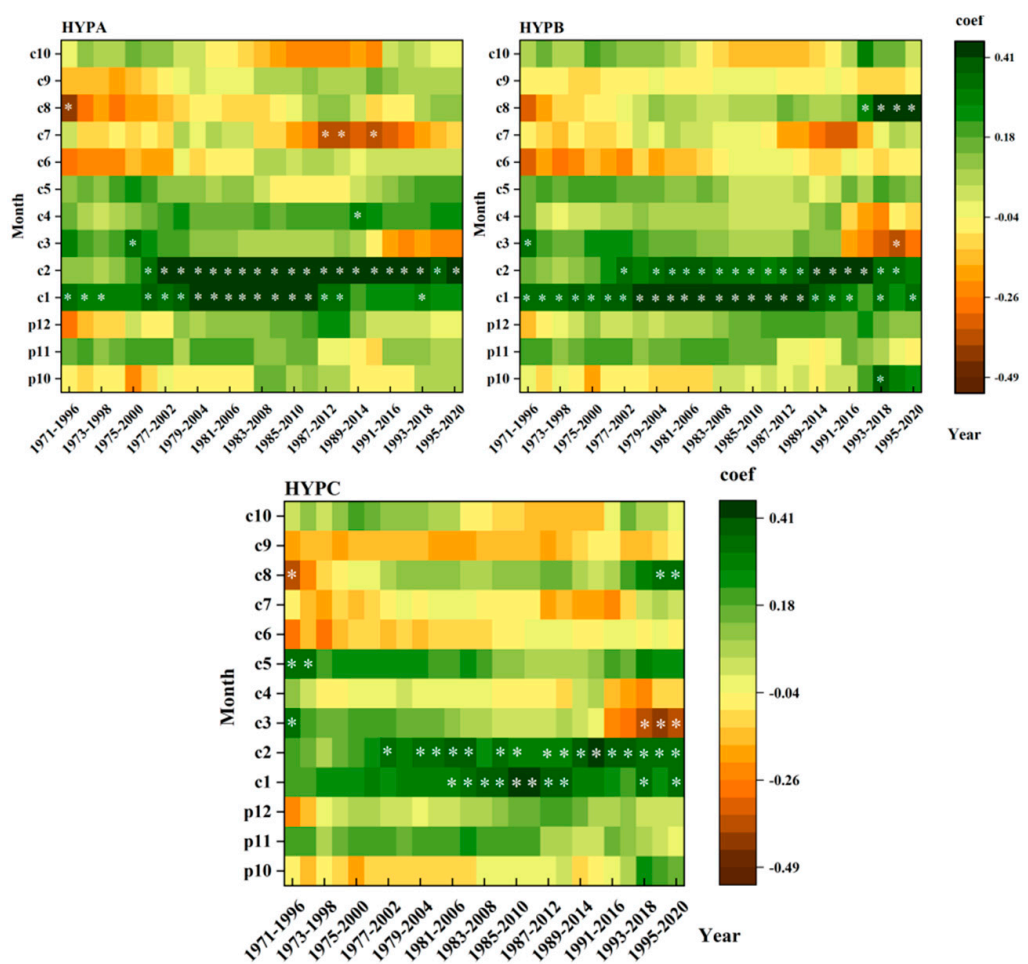

Figure 11. Sliding analysis results of the L. principis-rupprechtii tree-ring width index values derived at different elevations and precipitation from October of the previous year to October of the current year (with a sliding window of 26 years; $p$ represents the previous year; $c$ represents the current year; and the * symbol represents a significant correlation at the 0.05 level).
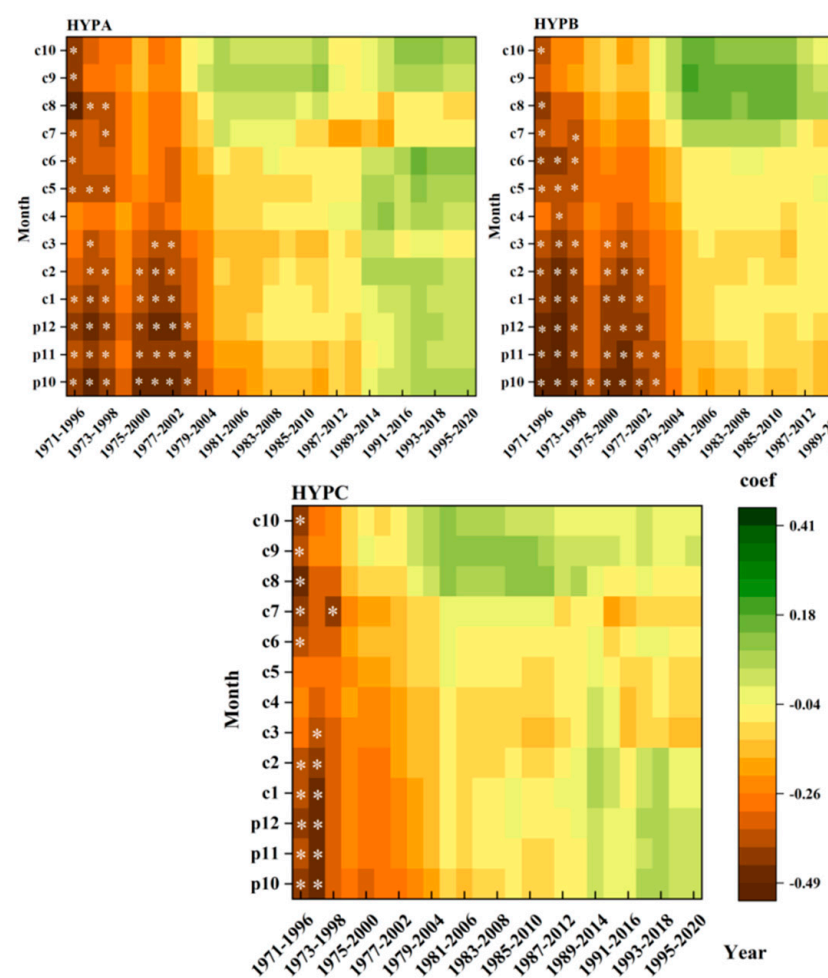

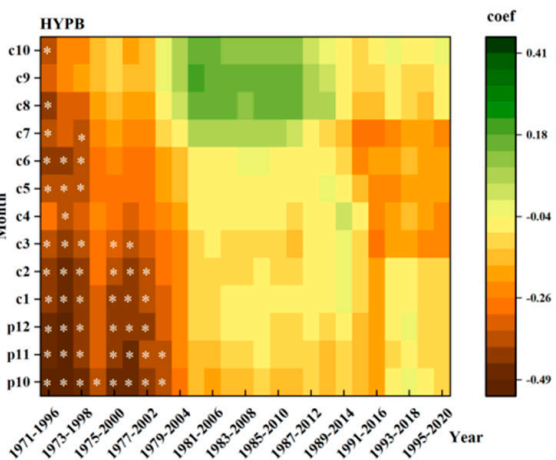

coef

Figure 12. Sliding analysis results of the L. principis-rupprechtii tree-ring width index values obtained at different elevations and the PDSI values from October of the previous year to October of the current year (with a sliding window of 26 years; $p$ represents the previous year; $c$ represents the current year; and the ${ }^{*}$ symbol represents a significant correlation at the 0.05 level). 


\section{Discussion}

\subsection{Differences in L. principis-rupprechtii Radial Growth at Different Elevations}

Chronological feature values can reflect the degrees of correlation between the radial growth of trees in the study area and climatic factors. The high standard deviation, mean sensitivity, signal-to-noise ratio and expressed population signal of the collected samples indicate that the chronologies contain rich climate information and can be used to study treering climatology and ecology [5]. While these chronologies are rich in climate information, they present change characteristics with obvious differences between low, middle and high elevations.

As the elevation increased, the signal-to-noise ratio and expressed population signal of the sample showed trends of first increasing and then decreasing, indicating that the midelevation area was highly sensitive to climatic factors and that the trees were growing well. First, the tree growth status is determined by the heterogeneity of the growth environment of the tree [61], as the environment affects the growth and physiological and ecological characteristics of L. principis-rupprechtii. The low-elevation trees sampled in this study were located in the transition zone between shrubs and coniferous forests, while the highelevation trees were located in the transition zone between coniferous forests and alpine meadows. In these regions, interspecies hybrids compete for habitats and inhibit the growth and development of L. principis-rupprechtii. The species is a positive vegetation type that is resistant to harsh conditions and has strong adaptability to the surrounding environment. L. principis-rupprechtii prefers deep, fertile, moist acidic or neutral soils with good drainage conditions and has a well-developed root system and strong resistance to wind. The dominant species in the sampled mid-elevation area include P. meyeri and $L$. principis-rupprechtii, both of which belong to coniferous forests and are well adapted to the local environmental conditions. Finally, the radial growth of L. principis-rupprechtii is influenced by varying climatic factors and growing season lengths. Temperatures in highelevation areas decrease with increasing elevation and are relatively low. The physiological activity of trees is affected by these low temperatures, and the overall material transmission speed decelerates. At the same time, as the temperature decreases, the length of the growing season shortens, and the sensitivity of the growing season to climate conditions also decreases $[62,63]$. The changing laws and characteristics of this type of tree growth vary with elevational gradients. Compared with the results of Kang Yongxiang et al. (2010), who studied Larix chinensis [7] specimens growing at different elevations on Taibai Mountain, Yang Raoqiong et al. (2018), who studied Pinus yunnanensis [14] growing at different elevations on Yulong Snow Mountain, and Bai Tianjun et al. (2020), who studied Cryptomoria japonica [64] growing at different elevations on Lushan Mountain, the results obtained in this study were basically consistent.

\subsection{Correlations between L. principis-rupprechtii Radial Growth and Climatic Factors at Different Elevations}

From the long-term seasonal-scale analysis, most of the tree-ring width chronologies obtained for L. principis-rupprechtii trees sampled at three elevations were significantly positively correlated with the monthly maximum temperature in spring. Increasing temperatures in spring cause snow to melt earlier, and trees thus end their dormancy earlier, prolonging the growing season and making the trees susceptible to forming wide rings in the corresponding year. From the perspective of tree physiology, in the early period of the tree-growing season, increasing temperatures in spring are conducive to increasing the photosynthetic activity of trees and promoting the accumulation of organic matter and the formation of nutrients [48,65-67], thus accelerating the elongation rate of cambium cell division in trees [68] and forming wider, earlier wood-growth rings. The low-elevation tree-ring width chronology obtained herein was significantly positively correlated with winter precipitation. Precipitation (snow) is beneficial to the accumulation of nutrients and soil moisture conservation and provides favorable conditions for the springtime growth of timber in the following year $[20,69]$. In subtropical, warm-temperate, and mid-temperate 
regions, many tree species are not completely dormant in winter. Under suitable temperature and rainfall conditions, tree cambium cells carry out various life activities, continue to accumulate carbon assimilation products, and provide essential nutrients for early wood throughout the winter [70]. The mid-elevation tree-ring width chronology was significantly negatively correlated with the springtime PDSI. The PDSI is an important soil drought indicator that not only considers the absorption of soil moisture but also integrates factors such as air temperature, surface evaporation, and runoff to form a comprehensive manifestation of effective soil moisture, temperature, and precipitation. The mid-elevation terrain studied herein exhibits small fluctuations, and water currents gather in low areas. The local area is the source of the Fen River, and many underground rivers and sufficient runoff can be found in this area. In the early stage of the growing season of L. principis-rupprechtii, the soil water content exceeds its growth requirements; thus, the tree roots are immersed in a wet (saturated) environment and absorb nutrients when material obstructions occur in the soil. This process is not conducive to the growth of trees. Many other areas of China also exhibit examples of significant negative correlations between tree growth and the PDSI. Humidity conditions are no longer considered a factor restricting the growth of trees in a specific area, as demonstrated in studies of subalpine coniferous forests on the western Sichuan Plateau [71], subalpine P. massoniana in Hanzhong, Shaanxi [72], and P. massoniana in the Jigongshan Nature Reserve in Xinyang, Henan [73].

From the monthly scale analysis, the low-elevation tree-ring width index chronology obtained herein was significantly positively correlated with the mean temperature in January of the current year. In contrast, from the perspective of tree physiology, low winter temperatures cause permafrost and mountain snow to last for a longer period of time. In the following year, more heat is required to thaw and melt this snow, thus slowing the increase of ground temperatures in spring and leading to a delay in the early wood growth of trees in the coming year. Low winter temperatures damage plant tissues and cells, thus reducing the growth potential and photosynthetic rate of trees in the coming year; thus, these low temperatures are not conducive to the formation of wide tree rings $[64,74]$. The low- and mid-elevation tree-ring width index chronology was significantly positively correlated with the mean temperature in November of the current year. Warm November temperatures can effectively prevent the freezing of tree leaf tissues and ensure normal metabolic activities, thereby allowing trees to accumulate the required amounts of energy and promoting the radial growth of trees in the coming year [6].

The low-elevation tree-ring width chronology was significantly positively correlated with the minimum temperatures in June of the previous year and showed a certain "lag effect" in response to climatic factors. June is the beginning of the rainy season, and local trees grow with sufficient water conditions during this time. With the arrival of the rainy season, the number of sunny days decreases, and the temperature drops. Summer is the most vigorous period of tree growth, and lower temperatures are not conducive to photosynthesis or the accumulation of photosynthetic products in trees, thereby inhibiting the growth of trees [59]. Similar conclusions have been reported in tree-ring studies of Lijiang spruce on Yulong Snow Mountain [59], Siberian larch on Altai Mountain [75] and red pine on Changbai Mountain [76]. The mid-elevation chronology was significantly negatively correlated with the minimum temperatures in July of the current year. July is the season with the most precipitation and the highest temperature in Guancen Mountain. Temperature has a threshold effect on tree growth. When the minimum temperature remains within a certain range, growth is promoted, but when the minimum temperature exceeds the threshold required for tree growth, growth is inhibited [77,78].

The mid-elevation tree-ring width index derived herein was significantly positively correlated with the monthly maximum temperatures in the late summer and early autumn of the previous year and with the monthly maximum temperatures during the entire growing season of the current year. Within the temperature threshold range required for normal L. principis-rupprechtii growth, the lower the monthly minimum temperature is, the less conducive it is to tree growth, while the higher the monthly maximum temperature 
is, the more conducive it is to tree growth $[77,79]$. A significant positive correlation can be found between the tree-ring width index derived at middle elevations and the maximum temperature in November. In northern China, trees basically stop growing in November but exhibit weak physiological activities. A higher monthly maximum temperature can increase the photosynthesis rate of trees, promote the synthesis and storage of organic substances, and create favorable conditions for the growth of trees in the next year. At the same time, higher temperature conditions extend the growing season of trees and allow them to accumulate more nutrients $[6,80,81]$. The high-elevation tree-ring width chronology was significantly positively correlated with the maximum temperatures in January of the current year. Trees are not completely dormant in January, and respiration is the main physiological activity of trees. Warm January temperatures can reduce the loss of carbohydrates stored in the previous growing season and are thus conducive to the growth of trees in the current year [64].

The mid-elevation tree-ring width index derived in this study was significantly negatively correlated with the precipitation and PDSI in September of the previous year. The precipitation in the Guancen Mountain area from June to September accounts for approximately $70 \%$ of the annual precipitation. L. principis-rupprechtii prefers deep, fertile, moist, and well-drained acidic or neutral soils. When precipitation reaches the threshold required for the growth of L. principis-rupprechtii, the presence of too much water slows the respiration of the tree roots, and corrosion of the roots seriously affects the growth and development of trees. This conclusion is consistent with the research results obtained by Zhang Wentao and other scholars on Luya Mountain [77]. The mid-elevation tree-ring width index was significantly negatively correlated with the PDSI values in March, May and June of the current year. The PDSI can effectively reflect the impact of soil moisture on tree growth and can be used as an important indicator to measure the amount of water available for plant growth and characterize drying and wetting changes in a study area [82]. In northern China, high temperatures and drought conditions restrict the growth of crops in most areas during the crop-growing period. However, local climate types vary and microclimates can be more conducive to crop growth. Guancen Mountain is the birthplace of the Fen River and has abundant groundwater resources. The terrain at middle elevations has small fluctuations and easily accumulates runoff, and the soil moisture is high. In late spring and early summer, which constitute the early growing season, the amount of water required for tree growth is not high compared with that required during the rest of the growing season. Thus, the water conditions at middle elevations can meet the growth needs of L. principis-rupprechtii, while excessive water conditions can inhibit respiration and the transmission of nutrients through root tissues. These results indicate that the PDSI is not the main factor restricting tree growth during the early period, as the humidity conditions in the study area are sufficient to meet the growth and development demands of trees. This region is not restricted by drought, which is a characteristic inherently related to the local unique small regional climate. This article only presents a study in a small local area, and it is necessary to further explore the relationship between the growth of other trees and the drought index in this area $[6,56,60,74]$.

The high-elevation tree-ring width index had certain correlations with climatic factors, but most did not reach significance. Further proving the conclusions discussed in Section 4.1, the mid-elevation tree-ring width index responded most obviously to climate factors, while the high-elevation tree-ring width index responded to climatic factors decreasing $[56,83]$.

The correlation analysis results obtained for L. principis-rupprechtii tree-ring width chronologies and monthly climate factors at different elevations show that the radial growth of low-elevation L. principis-rupprechtii is mainly restricted by spring temperatures, winter precipitation and the mean temperatures in January and November; the radial growth of mid- and high-elevation L. principis-rupprechtii is mainly restricted by the maximum temperature in the summer and early autumn months of the previous year and in the current growing season; and mid-elevation trees are most affected by extreme temperatures. 
At the turn of spring and summer at middle elevations, the radial growth of trees is not restricted by drought conditions and presents a significant level.

\subsection{Stability of L. principis-rupprechtii Radial Growth and Climatic Factors at Different Elevations}

In the past 50 years, the annual mean temperature recorded on Guancen Mountain has increased at a rate of $0.431{ }^{\circ} \mathrm{C} / 10 \mathrm{a}$, the annual precipitation has increased at a rate of $11.73 \mathrm{~mm} / 10 \mathrm{a}$, and the PDSI has decreased at a rate of 0.286/10a (Figure 4). With the acceleration of climate change, the response laws of tree growth and climatic factors in different regions have changed. Trees have individual limits of tolerance to climatic factors. Abnormal changes in climate factors can cause the radial growth of trees to differentiate from changes in temperature and precipitation $[24,84,85]$. The entire study area presents a warm and dry climate state, and the radial growth of L. principis-rupprechtii at different elevations in this area presents a "differentiation phenomenon" under the background of climate change. From 1993-2018, the tree-ring width index characterizing trees at mid-high elevations and the mean temperature in the spring of the current year became significantly positively correlated, showing a change from the previous negative correlation. With the trend of climate warming, early spring temperatures will increase rapidly, thus advancing the growing season of trees to a certain extent and creating beneficial conditions for trees to form wide rings. At the same time, the forest limit will develop to a higher elevation, thus helping to expand the habitat range. From 1976 to 2001, the low- and high-elevation tree-ring width indexes and February precipitation began to show significant positive correlations. The three elevational ranges studied herein were significantly constrained by precipitation in January on a long-term scale. In the northern region of China in January and February, winter precipitation usually exists in the form of snowfall. Snowfall acts as an insulation layer for the roots of trees, and the springtime melting of snow provides water for the growth of trees in early spring. The three-elevation tree-ring width chronologies and PDSI values changed from significantly negatively correlated to nonsignificantly negatively and positively correlated, suggesting that the growth of L. principis-rupprechtii on Guancen Mountain is restricted by drought conditions under warming and drying background climate conditions.

\section{Conclusions}

In this study, data from ring core samples of a dominant species, L. principis-rupprechtii, growing at different elevations along the forest line ecotones on Guancen Mountain were used as proxy data to establish standard tree-ring width chronologies characterizing different elevations using the dendroclimatology research method. The correlations between the obtained tree-ring width indexes characterizing the three elevational gradients and monthly climatic factors were examined, RDA and sliding analysis were performed to further verify the correlation and response results and to further analyze the dynamic relationships between the derived tree-ring width indexes and climatic factors on a long-term scale. The following conclusions were obtained in this research.

(1) The standard tree-ring width chronologies obtained at the three sampled elevations all had high mean sensitivities, signal-to-noise ratios and expressed population signals in the corresponding samples, indicating that Guancen Mountain is suitable for tree-ring climatology analysis and is sensitive to the powerful effects of climate change. Compared with the low-elevation chronology, the mid- and high-elevation tree-ring width chronologies had more significant characteristic values, indicating that mid- and high-elevation L. principisrupprechtii are more sensitive to climate responses than low-elevation L. principis-rupprechtii and present key responses to climate change.

(2) The radial growth of low-elevation L. principis-rupprechtii is restricted by both the local temperature and precipitation conditions, while the radial growth of mid- and highelevation L. principis-rupprechtii is mainly restricted by the local temperature conditions. The radial growth of low-elevation L. principis-rupprechtii is mainly affected by the springtime mean temperatures and the wintertime precipitation. 
(3) The main climatic factor controlling the radial growth of mid- and high-elevation L. principis-rupprechtii is the monthly maximum temperature. The radial growth of midelevation L. principis-rupprechtii shows a certain "lag effect" in response to climatic factors, and this effect is significantly negatively correlated with the precipitation and PDSI measured in September of the previous year. The radial growth of mid-elevation trees is not restricted by drought conditions in spring and early summer and is inherently related to the unique geographic location of the studied mid-elevation region.

(4) The long-term scale sliding analysis suggested that the tree-ring width index derived for L. principis-rupprechtii trees growing at middle and high elevations reflects a significant response to the springtime mean temperature after 1993, which has become the main factors restricting tree growth at middle and high elevations. January and February precipitation are the main long-term factors controlling the radial growth of L. principisrupprechtii at different elevations on Guancen Mountain. Over a long time period, the PDSI was positively correlated with the chronological indexes obtained at the three sampled elevations, indicating that the radial growth of L. principis-rupprechtii, as a dominant species, was restricted by drought conditions under the warming and drying climate change trends in the Guancen Mountain area.

Author Contributions: S.L. and J.W. conceived the idea; J.W. and Y.G. performed the experiment; J.W., Q.Y., R.R. and Y.H. analyzed data; J.W. wrote the manuscript; S.L. reviewed and approved the final manuscript. All authors have read and agreed to the published version of the manuscript.

Funding: The research was funded by a General Program from the Natural Science Foundation of Shaanxi Province (no. 2014JQ5172), the Open Fund Project of the State Key Laboratory of Loess and Quaternary Geology (no. SKLLQG1611), and the National Forestry Public Welfare Industry Scientific Research Project of China (no. 201304309).

Data Availability Statement: The data presented in this study are available on request from the corresponding author.

Conflicts of Interest: The authors declare no conflict of interest.

\section{References}

1. Nowacki, G.J.; Abrams, M.D. The Demise of Fire and “Mesophication" of Forests in the Eastern United States. BioScience 2008, 58, 123-138. [CrossRef]

2. Nowacki, G.J.; Abrams, M.D. Is climate an important driver of post-European vegetation change in the Eastern United States? Glob. Chang. Biol. 2015, 21, 314-334. [CrossRef] [PubMed]

3. Lindner, M.; Maroschek, M.; Netherer, S.; Kremer, A.; Barbati, A.; Garcia-Gonzalo, A.; Seidl, R.; Delzon, S.; Corona, P.; Kolström, M.; et al. Climate change impacts, adaptive capacity, and vulnerability of European forest ecosystems. For. Ecol. Manag. 2010, 259, 698-709. [CrossRef]

4. Engelbrecht, B.M.J. Forests on the brink: An analysis of the physiological vulnerability of different trees to drought shows that forests around the globe are at equally high risk of succumbing to increases in drought conditions. Nature 2012, 491, 675-676. [CrossRef] [PubMed]

5. $\mathrm{Wu}, \mathrm{X}$; Shao, X. A Preliminary analysis on response of tree-ring density to climate in the Qinling Mountains of China. Chin. J. Appl. Ecol. 1994, 5, 253-256.

6. Qin, J.; Bai, H.; Zhou, Q.; Wang, J.; Li, S.; Gan, Z.; Bao, G. Radial growth response of Abies fargesii to climate change from different elevations at timberline of Niubeiliang Natural Reserve. Arid Land Geogr. 2017, 40, 147-155. (In Chinese)

7. Kang, Y.; Liu, J.; Dai, S.; He, X. Characteristics of ring-width chronologies of Larix chinensis and their responses to climate change at different elevations in Taibai Mountain. J. Northwest Univ. 2010, 38, 141-147. (In Chinese)

8. Wu, X. Application of tree ring analysis to the study on environment variation. Quat. Sci. 1990, 10, 188-196. (In Chinese)

9. Yang, Y.; Liu, Y.; Shi, J.; Cai, Q.; Song, J.; Yi, L.; Li, Q.; Sun, H. Experimental method of density for tree-ring research and Its application in research of tree ring data from Zhungeer County. Inn. Mongalia (In Chinese). 2006, 29, 639-645. (In Chinese)

10. Christian, Z.; Franco, B. Dendroclimatic calibration in R: The bootRes package for response and correlation function analysis. Dendrochronologia 2013, 31, 68-74. [CrossRef]

11. Preechamart, S.; Pumijumnong, N.; Payomrat, P.; Buajan, S. Variation in climate signals in Teak tree-ring chronologies in two different growth areas. Forests 2018, 9, 772. [CrossRef]

12. Klesse, S.; von Arx, G.; Gossner, M.M.; Hug, C.; Rigling, A.; Queloz, V. Amplifying feedback loop between growth and wood anatomical characteristics of Fraxinus excelsior explains size-related susceptibility to ash dieback. Tree Physiol. 2021, 41, 683-696. [CrossRef] [PubMed] 
13. Zhang, H.; Shao, X.; Zhang, Y. Research progress on the response of radial growth to climatic factors at different altitudes. J. Earth Environ. 2012, 3, 845-854. (In Chinese)

14. Yang, R.; Fan, Z.; Li, Z.; Wen, Q. Radial growth of Pinus yunnanensis at different elevations and their responses to climatic factors in the Yulong Snow Mountain, northwest Yunnan, China. Acta Ecol. Sin. 2018, 38, 8983-8991. (In Chinese)

15. Zhang, Y.; Bergeron, Y.; Gao, L.; Zhao, X.; Wang, X.; Drobyshev, L. Tree growth and regeneration dynamics at a mountain ecotone on Changbai Mountain, northeastern China: Which factors control species distributions? Ecol. Sci. 2014, 21, 387-404. [CrossRef]

16. Panthi, S.; Brauning, A.; Zhou, Z.; Fan, Z. Growth response of Abies georgei to climate increases with elevation in the central Hengduan Mountains, southwestern China. Dendrochronologia 2018, 47, 1-9. [CrossRef]

17. Fan, Z.; Brauning, A.; Cao, K.; Zhu, S. Growth-climate responses of high-elevation conifers in the central Hengduan Mountains, southwestern China. For. Ecol. Manag. 2009, 258, 306-313. [CrossRef]

18. Chen, L.; Yin, Y.; Zhao, D.; Yuan, Q.; Wu, S. Climate response of tree growth along an altitudinal gradient in the Changbai Mountains, northeast China. Acta Ecol. Sin. 2014, 34, 1568-1574. (In Chinese)

19. Oberhuber, W.; Kofler, W. Topographic influences on radial growth of Scots pine (Pinus sylvestris L.) at small spatial scales. Plant. Ecol. 2000, 146, 231-240. [CrossRef]

20. Sang, W.; Wang, Y.; Su, H.; Lu, Z. Response of tree-ring width to rainfall gradient along the Tianshan Mountains of northwestern China. Chin. Sci. Bull. 2007, 52, 2954-2962. [CrossRef]

21. Esper, J.; Frank, D.C.; Wilson, R.J.S.; Büntgen, U.; Treydte, K. Uniform growth trends among central Asian low- and high-elevation juniper tree sites. Trees 2007, 21, 141-150. [CrossRef]

22. Dario, M.B.; Nell, P. Convergence in drought stress, but a divergence of climatic drivers across a latitudinal gradient in a temperate broadleaf forest. J. Biogeogr. 2015, 42, 925-937. [CrossRef]

23. D'Arrigo, R.; Wilson, L.; Liepert, B.; Cherubini, P. On the divergence problem' in northern forests: A review of the tree-ring evidence and possible causes. Glob. Planet. Chang. 2008, 60, 289-305. [CrossRef]

24. Kurz-Besson, C.B.; Lousada, J.L.; Gaspar, M.J.; Correia, I.E.; David, T.S.; Soares, P.M.; Cardoso, R.M.; Russo, A.; Varino, F.; Mériaux, C.; et al. Effects of recent minimum temperature and water deficit increases on Pinus pinaster radial growth and wood density in southern Portugal. Front. Plant Sci. 2016, 7, 1170. [CrossRef] [PubMed]

25. Xu, M.; Bai, H.; Ji, Q.; Li, M.; Ma, C.; Li, X.; Yang, C. Variations of plant community diversity with latitudinal gradients in Lvliang Mountains in Shanxi Province. Value Eng. 2016, 20, 198-201. (In Chinese)

26. Qin, L.; She, L. Studies on the plant diversity in Guancen Mountains forest area. J. Taiyuan Norm. Univ. 2011, 10, 142-146. (In Chinese)

27. Wang, Z.; Li, Q.; Liu, Y.; Yang, Y.; Ren, M.; Cui, L. PDSI variations recorded by tree rings in the northern Lvliang Mountains during the past 175 years. J. Earth Environ. 2020, 11, 72-80. (In Chinese)

28. Pompa-García, M.; Cerano-Paredes, J.; Fuléa, P.Z. Variation in radial growth of Pinus cooperi in response to climatic signals across an elevational gradient. Dendrochronologia 2013, 31, 198-204. [CrossRef]

29. Shrestha, K.B.; Chhetri, P.K.; Bista, R. Growth responses of Abies spectabilis to climate variations along an elevational gradient in Langtang National Park in the central Himalaya, Nepal. J. For. Res. 2017, 22, 274-281. [CrossRef]

30. Babushkina, E.; Belokopytova, L.; Zhirnova, D.; Barabantsova, A.; Vaganov, E. Divergent growth trends and climatic response of Picea obovata along elevational gradient in Western Sayan mountains, Siberia. J. Mt. Sci. 2018, 15, 2378-2397. [CrossRef]

31. Cai, Q.; Liu, Y.; Bao, G.; Lei, M.; Sun, B. Tree-ring-based May-July mean temperature history for Lvliang Mountains. Chin. Sci. Bull. 2010, 55, 2033-2039. (In Chinese)

32. Li, Q.; Liu, Y.; Cai, Q.; Sun, J.; Yi, L.; Song, H.; Wang, L. Reconstruction of annual precipitation since 1688A.D. from Ningwu region, Shanxi Province. Quat. Sci. 2006, 26, 999-1006. (In Chinese)

33. Yi, L.; Liu, Y.; Song, H.; Li, Q.; Cai, Q.; Yang, Y.; Sun, J. Summer temperature variations since 1676 AD in Luya Mountain, Shanxi province of China, inferred from tree rings. J. Glaciol. Geocryol. 2006, 28, 330-336. (In Chinese)

34. Zhang, W.; Jing, Y.; Wang, M.; Zhang, L.; Dong, M.; Guo, Y. Responses of radial growth to climate warming in Picea meyeri trees growing at different elevations on the southern slope of Luya Mountain. Chin. J. Plant Ecol. 2013, 37, 1142-1152. (In Chinese) [CrossRef]

35. Zhang, W.; Jiang, Y.; Wang, M.; Zhang, L.; Dong, M. Responses of radial growth in Larix principis-rupprechtii to climate change along an elevation gradient on the southern slope of Luya Mountain. Acta Ecol. Sin. 2015, 35, 6481-6488. (In Chinese)

36. Li, Y.; Wang, S.; Niu, J.; Fang, K.; Li, X.; Li, Y.; Bu, W.; Li, Y. Climate-radial growth relationship of Larix principis-rupprechtii at different altitudes on Luya Mountain. Acta Ecol. Sin. 2016, 36, 1608-1618. (In Chinese)

37. Hao, X.; Shangguan, T. Plant species diversity of the forestry community in Guancen Mountain at the source of Fen River of Shanxi. J. Anhui Agric. Sci. 2009, 37, 6232-6235. (In Chinese)

38. Ma, L. Study on biodiversity characteristic in Guancen Mountain. Shaanxi For. Sci. Technol. 2014, 43, 19-21. (In Chinese)

39. Xie, M. Investigation on typical vegetation communities and ancient and famous trees in Guancen mountain forest area. Inn. Mong. For. Investig. Des. 2015, 38, 90-93. (In Chinese)

40. An, S. Vertical distribution law of forest vegetation and soil types in Guancen Mountai. Shaanxi For. Sci. Technol. 1998, 2, 20-22. (In Chinese)

41. Zhai, D.; Zhang, T. Vegetation and its utilization in Guancen mountain. J. Shaanxi Norm. Univ. 1992, 4, 39-43. (In Chinese) 
42. Fang, K.; Yang, B.; Zheng, H. Research methods of dendrochronology and its application in global change. Quat. Sci. 2015, 35, 1283-1293. (In Chinese)

43. Stokes, M.A.; Smiley, T.L. An Introduction to Tree-Ring Dating; University of Chicago Press: Chicago, IL, USA, 1968.

44. Fritts, H. Tree Rings and Climate; Academic Press: London, UK, 1976; pp. 511-529.

45. Holmes, R.L. Computer-assisted quality control in tree-ring dating and measurement. Tree-Ring Bull. 1983, 43, 69-75.

46. Holmes, R.; Adams, R.; Fritts, H. Tree-Ring Chronologies of Western North America: California, Eastern Oregon and Northern Great Basin. Chronology Series VI; Laboratory of Tree-Ring Research, University of Arizona: Tucson, AZ, USA, 1986.

47. Cook, S.P.; Hain, F.P. Defensive mechanisms of loblolly and shortleaf pine against attack by southern pine beetle, Dendroctonus frontalis Zimmermann, and its fungal associate, Ceratocystis minor (Hedgecock). Hunt. J. Chem. Ecol. 1986, 12, 1397-1406. [CrossRef]

48. Wu, X. Tree Rings and Climate Change; Beijing Meteorological Press: Beijing, China, 1990.

49. Chen, Y.; Chen, F.; Zhang, H.; Hu, M.; Wang, S. Strong link of large volcanic eruptions and climatic and hydrological changes recorded by tree rings in the river source area of Southern High Asia since 1200 A.D. Quat. Sci. 2021, 41, 323-333. (In Chinese)

50. Liu, G.; Guo, A.; An, S.; Liu, W. Research progress in Palmer drought severity index and it's application. J. Nat. Disaster 2004, 13, 21-27. (In Chinese)

51. An, S.; Xing, J. Correction of Palmer drought severity model. Bull. Acad. Meteorol. Sci. 1986, 1, 75-82. (In Chinese)

52. Wei, J.; Ma, Z. Comparison of palmer drought severity index, percentage of precipitation anomaly and surface humid index. Acta Geogr. Sin. 2003, 58, 117-124. (In Chinese)

53. Braak, C. Canonical community ordination. Part I: Basic theory and linear methods. Ecol. Sci. 1994, 1, 127-140. [CrossRef]

54. Olivier, T.; Masayoshi, N.; Zhao, H. Rare earth alkyl and hydride complexes bearing silylene-linked cyclopentadienyl-phosphido ligands. Synthesis, structures, and catalysis in olefin hydrosilylation and ethylene polymerization. Tetrahedron 2003, 59, 1052510539. [CrossRef]

55. Biondi, F.; Waikul, K. DENDROCLIM2002: A C++ program for statistical calibration of climate signals in tree-ring chronologies Comput. Geosci. 2004, 30, 303-311. [CrossRef]

56. Zhao, X.; Bai, X.; Li, J.; Wang, L.; Zhang, X.; Lu, X.; Chen, Z. Response of Larix olgensis at different elevations to climate change in the context of climate warming. Chin. J. Ecol. 2019, 38, 637-647. (In Chinese)

57. Wigley, T.; Briffa, K.; Jones, P. On the average value of correlated time series, with applications in dendroclimatology and hydrometeorology. J. Climatol. Appl. Meteorol. 1984, 23, 201-213. Available online: https://www.jstor.org/stable/26181323 (accessed on 9 October 2021). [CrossRef]

58. Han, Y.; Zhou, W.; Qi, L.; Zhou, L.; Zhong, Q.; Dai, L.; Yu, D. Tree radial growth-climate relationship in Changbai Mountain, Northeast China. J. Appl. Ecol. 2019, 30, 1513-1520. (In Chinese)

59. Zhang, Y.; Yin, D.; Tian, K.; Zhang, W.; He, R.; He, W.; Sun, J.; Liu, Z. Radial growth responses of Picea likiangensis to climate variabilities at different altitudes in Yulong Snow Mountain, southwest China. Chin. J. Plant Ecol. 2018, 42, 629-639. (In Chinese)

60. Yu, J.; Xu, Q.; Liu, C.; Luo, C.; Yang, J.; Li, J.; Liu, Q. Response of radial growth to climate change for Larix olgensis along an altitudinal gradient on the eastern slope of Changbai Mountain, northeast China. Chin. J. Plant Ecol. 2016, 40, 24-35. (In Chinese)

61. Pan, H.L.; Li, M.H.; Cai, X.H.; Wu, J.; Du, Z.; Liu, X.L. Responses of growth and ecophsiology of plants to altitude. Ecol. Environ. Sci. 2009, 18, 722-730.

62. Korner, C. Paradigm shift in plant growth control. Curr. Opin. Plant Biol. 2015, 25, 107-114. [CrossRef]

63. Yang, B.; He, M.; Shishov, V.; Tychkov, L.; Vaganov, E.; Rossi, S.; Ljungqvist, C.; Bräuning, A.; Grießinger, J. New perspective on spring vegetation phenology and global climate change based on Tibetan Plateau tree-ring data. Proc. Natl. Acad. Sci. USA 2017, 114, 6966-6971. [CrossRef]

64. Bai, T.; Deng, W.; Kuang, Y.; Liu, Y.; Ye, Q.; Niu, J.; Wen, L. Response of tree ring width in Cryptomeria japonica to climatic factors at different elevations in Lushan Mountain. Chin. J. Ecol. 2020, 39, 57-66. (In Chinese)

65. Sun, Y.; Wang, L.; Chen, J.; Duan, J.; Shao, X.; Chen, K. Growth characteristics and response to climate change of Larix miller tree-ring in China. Sci. Chin. 2010, 40, 645-653. (In Chinese) [CrossRef]

66. Hughes, M.K.; Kelly, P.M.; Pilcher, J.R. Climate from Tree Rings; Cambridge University Press: Cambridge, UK, 1982.

67. Li, J.; Yuan, Y. The role of snow in the growth of tree rings. J. Xinjiang Univ. 1984, 1, 85-92. (In Chinese)

68. Begun, A.; Gerasimenyuk, N.; Korneev, A.; Molochkov, A.; Niemi, A. Gauge theory: Protein topology and dynamics. J. Bioenerg. Biomembr. 2018, 50, 500-501.

69. Zhu, H.; Wang, L.; Shao, X.; Fang, X. Tree ring-width response of Picea schrenkiana to climate change. Geogr. Sin. 2004, 59, 863-870. (In Chinese)

70. Gou, X.; Chen, F.; Jacoby, G.; Cook, E.; Yang, M.; Peng, J.; Zhang, Y. Rapid tree growth with respect to the last 400 years in response to climate warming, northeastern Tibetan Plateau. Int. J. Climatol. 2007, 27, 1497-1503. [CrossRef]

71. Chen, C. Response of Radial Growth of Subalpine Coniferous Forest to Climate in Daofu County, Sichuan Province. Master's Thesis, Chengdu University of Technology, Chengdu, China, 2019.

72. Feng, X.H.; Cheng, R.M.; Xiao, F.W.; Wang, R.L.; Wang, X.R.; Gao, B.Q. The influence of temperature in north subtropical growing period on the radial growth of Masson Pine. J. Ecol. 2011, 30, 650-655.

73. Cheng, R.; Feng, X.; Xiao, W.; Wang, R.; Wang, X.; Du, H. Response of net productivity of masson pine plantation to climate change in North Subtropical Region. Acta Ecol. Sin. 2011, 31, 2086-2095. (In Chinese) 
74. Zhang, T.; Yuan, Y.; Wei, W.; He, Q.; Zhang, R.; Yu, S.; Chen, F. Contrastive analysis and climate response of tree-ring width of Picea schrenkiana at the upper and lower forest limits in the middle section of the Kaiduhe River watershed. Arid Land Geogr. 2013, 36, 680-690. (In Chinese)

75. Xue, R.; Jiao, L.; Liu, X.; Chen, K. Evaluation of the stability of the radial growth of Larix sibirica at different altitudes in response to climate change in Altai Mountains, Xinjiang. Chin. J. Ecol. 2021, 40, 1275-1284. (In Chinese) [CrossRef]

76. Zhou, Z.; Jiang, Y.; Dong, M.; Tao, Y.; Wang, M.; Ding, X. Response of the relationship between radial growth and climatic factors to abrupt change of temperature along an altitudinal gradient on the northern slope of Changbai Mountain, northeast China. Acta Ecol. Sin. 2018, 38, 4668-4676. (In Chinese)

77. Zhang, W.; Jiang, Y.; Dong, M.; Yang, Y.; Yang, H. Larix principis-rupprechtii's radial growth-climate relationship at different elevations in Luya Mountains. J. Beijing Norm. Univ. 2011, 47, 304-309. (In Chinese)

78. Wu, X.; Jiao, L.; Du, D.; Qi, C.; Xue, R. Comparison of the radial growth response of Picea crassifolia to climate change in different regions of the central and eastern Qilian Mountains. Forests 2021, 12, 1015. [CrossRef]

79. Duan, J.; Wang, L.; Xu, Y.; Sun, Y.; Chen, J. Response of tree-ring width to climate change at different elevations on the east slope of Gongga Mountains. Geogr. Res. 2010, 29, 1940-1949. (In Chinese)

80. Zhang, Y.; Yin, D.; Tian, K.; He, R.; He, M.; Li, Y.; Sun, D.; Zhang, W. Relationship between radial growth of Abies georgei and climate factors at different altitudes on the eastern slope of Yulong Snow Mountain, China. Chin. J. Appl. Ecol. 2018, 29, $2355-2361$. (In Chinese)

81. Jiang, Y.; Cao, Y.; Han, S.; Zhang, J.; Hao, L. Spatial variation and temporal instability in the growth/climate relationship of White Birch (Betula platyphylla Suk) in the Changbai Mountain, China. Forests 2021, 12, 589. [CrossRef]

82. Chen, F.; Yuan, Y.; Wei, W.; Yu, S.; Zhao, Y.; Fan, Z.; Li, Y.; Zhang, R.; Zhang, T.; Shang, H. Variations of long-term palmer drought index in recent 354 years in Yili based on tree-ring record. Plateau Meteorol. 2011, 30, 355-362. (In Chinese)

83. Qiao, J.; Wang, T.; Pan, L.; Sun, Y. Responses of radial growth to climate change in Pinus massoniana at different altitudes and slopes. Chin. J. Appl. Ecol. 2019, 30, 2231-2240. (In Chinese)

84. Rossi, S.; Deslauriers, A.; Anfodillo, T.; Morin, H.; Saracino, A.; Motta, R.; Borghetti, M. Conifers in cold environments synchronize maximum growth rate of tree-ring formation with day length. New Phytol. 2006, 170, 301-310. [CrossRef]

85. Rossi, S.; Deslauriers, A.; Griçar, J.; Seo, J.-W.; Rathgeber, C.B.K.; Anfodillo, T.; Morin, H.; Levanic, T.; Oven, P.; Jalkanen, R. Critical temperatures for xylogenesis in conifers of cold climates. Glob. Ecol. Biogeogr. 2008, 17, 696-707. [CrossRef] 